Universidad de Lima

Facultad de Humanidades

Carrera de Comunicación

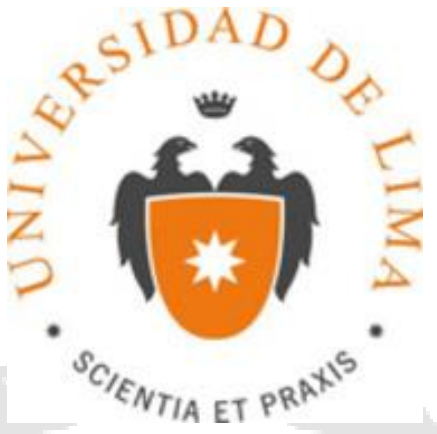

\title{
Violencia sexual, estereotipos y la política de representación: Análisis sobre casos de violencia sexual en prensa escrita peruana
}

Trabajo de investigación para optar por el título profesional de Licenciado en Comunicación

\section{Jimena Lucia Salinas Groppo}

Código 20111463

\section{Asesor}

Lilian Kanashiro Nakahodo

Lima - Perú

Agosto del 2016 


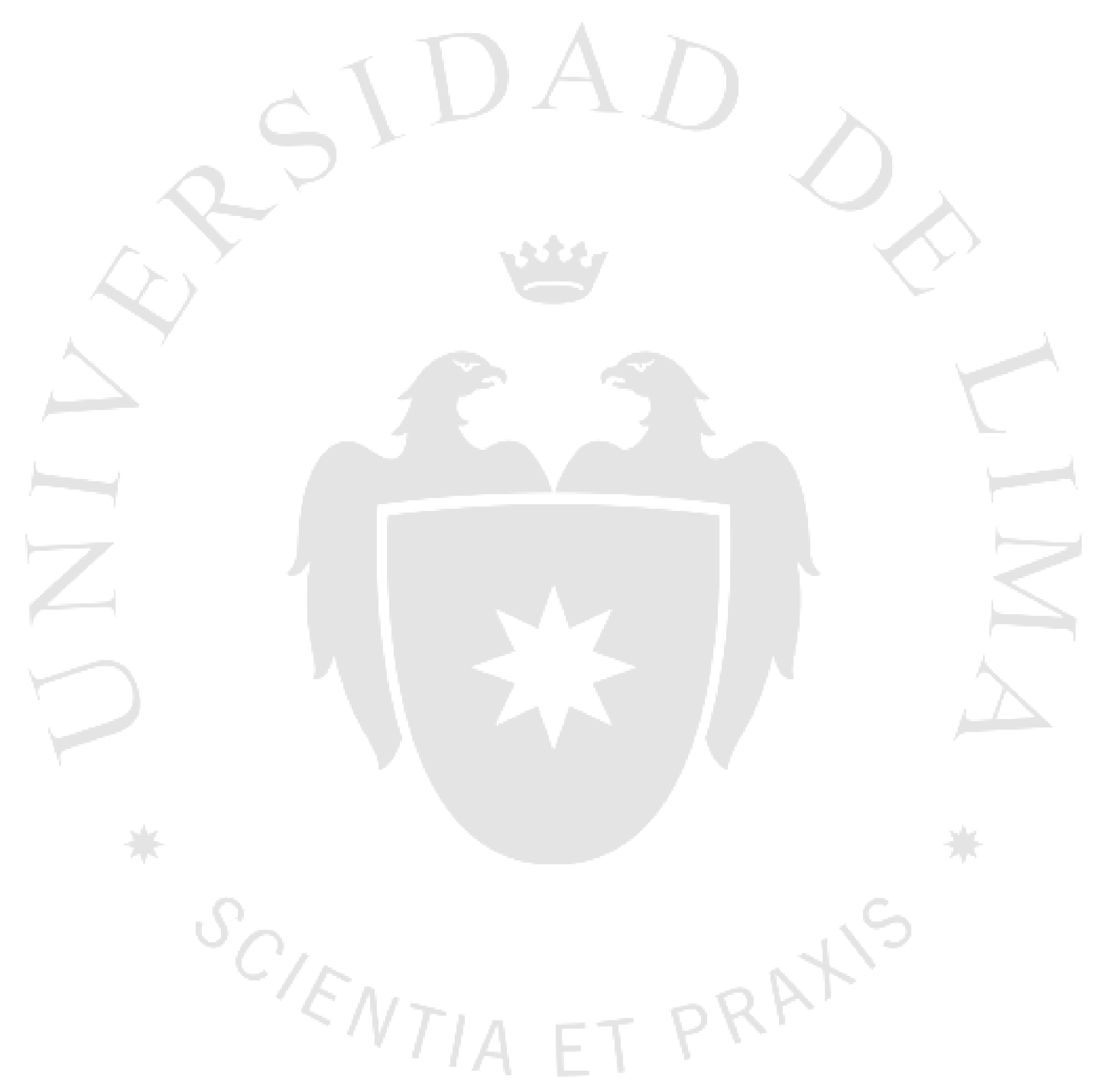


Violencia sexual, estereotipos y la política de representación: Análisis sobre casos de violencia sexual en prensa escrita peruana
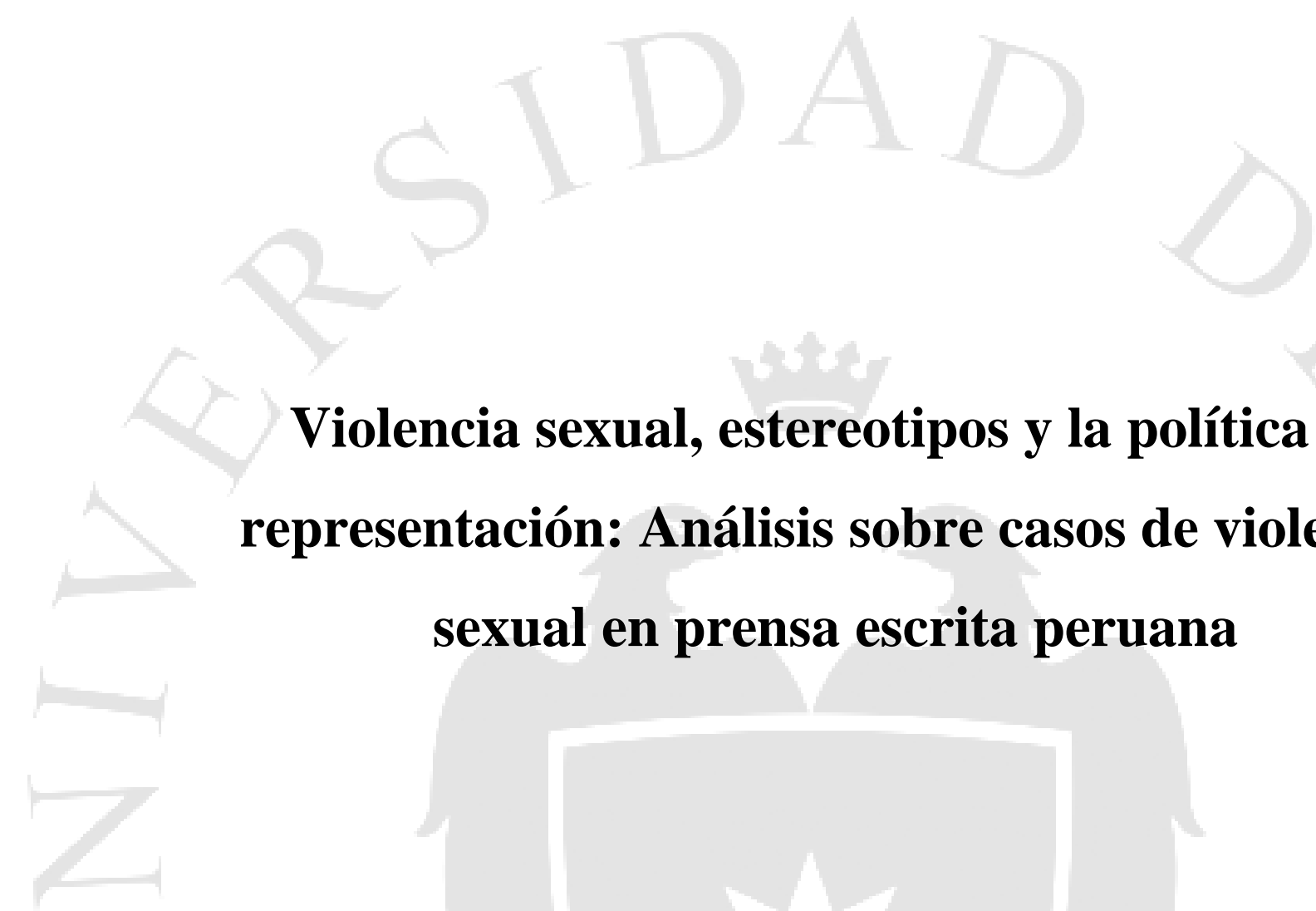


\section{ÍNDICE}

INTRODUCCIÓN ..............................................

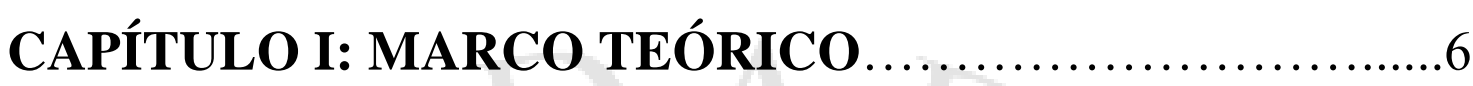

1.1 Estudios sobre la violencia sexual ...................6

1.2 Interaccionismo simbólico............................

1.3 La violencia, el género y la víctima..................9

1.4 Estereotipos y discurso mediático....................10

1.5 Marco referencial .................................11

CAPÍTULO II: METODOLOGÍA ..........................13

CAPÍTULO III: RESULTADOS ...........................16

3.1 Mitos y estereotipos..............................16

3.2 Proceso de victimización............................19

Conclusiones.............................................. 23

Referencias.......................................................

Anexos....................................................... 34

Sinopsis de casos.......................................

Cuadro de diseño metodológico...........................36

Cuadros de recojo de datos..............................37 


\section{INTRODUCCIÓN}

La violencia sexual es un tipo de violencia considerada como centro focal de la narrativa mediática, ya que tiende a ser disociada de la violencia en general y es integrada a una categoría propia e individual. La presencia de elementos afectivos o sexuales dentro de la violencia sexual genera una mayor repercusión mediática y capta con mayor facilidad el interés del lector. Es aquella constante inserción de la sexualidad en los medios la cual mantiene las estructuras sociales que reproducen estereotipos. En los discursos mediáticos, existe una asociación tácita entre el allanamiento corporal y el intercambio sexual, que permite insertar el lenguaje de medios judiciales para alimentar el contenido discursivo de la prensa. En el presente trabajo, se entiende la violencia o agresión sexual como cualquier intercambio carnal sin el consentimiento de ambas partes. (Fernández Díaz, 2003, pág. 24) Existe un límite entre la sexualidad y un acto de agresión sexual; no obstante, este tiende a ser desdibujado por la perpetuación de un discurso que asocia e intercambia ambos términos. Aquel límite es el referente a la voluntad y el deseo de la víctima. Pero existen dificultades al evaluar la presencia de la voluntad en casos de incidentes violentos y en el proceso se niega el deseo de la mujer o se le distorsiona mediante la presencia de la seducción o la provocación. Frente a la negación del deseo, la condescendencia o la entrega se convierten en sustitutos para éste en los discursos actuales.

¿Cuáles son los discursos presentes en la cobertura de prensa escrita peruana en relación a casos de violencia sexual y cómo se relacionan con la fabricación de estereotipos y el fenómeno de victimización? El objetivo de la presente investigación es analizar cómo el uso del lenguaje y la comunicación, empleada en la cobertura de prensa escrita peruana en relación a casos de violencia sexual, forjan la base de estereotipos y reflejan y reproducen las relaciones de poder y el proceso de victimización. Específicamente, se busca identificar la presencia de mitos y estereotipos a través de su lenguaje y el planteamiento del juicio mediático, al igual que analizar el manejo del poder simbólico y el proceso de victimización de la prensa escrita peruana y su dimensión persuasiva en relación a la comunicación de ideologías patriarcales. 


\section{CAPÍTULO I: MARCO TEÓRICO}

\subsection{Estudios sobre la violencia sexual}

El estado del arte en relación a la cobertura de casos de violaciones sexuales en medios de comunicación se divide en diversos enfoques. Algunos de ellos provienen del campo del psicoanálisis, de la sociología, de los estudios de género y de las ciencias de la comunicación, con un particular énfasis en el periodismo y la ética. No obstante, debido a la naturaleza del tema, los textos e investigaciones suelen abarcar una multitud de campos, motivo por el cual algunos optan por una óptica interdisciplinaria para abordar la problemática desde diversas perspectivas. En el área de la psicología y el psicoanálisis, la investigación suele centrarse en los efectos y secuelas psicológicas que derivan como resultado de la violencia sexual. Por ejemplo, una tesis de Victoria McCoy parte su investigación de la teoría del mundo justo de Lerner. (McCoy, 2004, pág. 16) Por otro lado, existe un enfoque que busca efectuar un análisis desde la sociología, el estructuralismo y el interaccionismo simbólico, como en el caso de Goffman y Laughey, donde se sintetizan todos los ámbitos sociales que pueden ser relacionados con la comunicación, especificando el rol de la perpetuación de estereotipos. (Laughey, 2008, pág. 4)

Asimismo, otra serie de estudios e investigaciones se concentran en relacionar el tema con los estudios de género o con la crítica feminista. Aquellos textos recogen teorías de género y sexualidad, como el libro de Judith Butler, el cual resalta la necesidad de "deshacer" las categorías rígidas de género. (Butler, 2006, pág. 14) De igual manera, otros libros basados en el mismo marco teórico, vinculan la temática con la violencia sexual de una manera más explícita, como el de Drew Humphries sobre la mujer, la violencia y los medios de comunicación. (Humphries, 2009, pág. 55). Dentro de las investigaciones recopiladas, un número mayoritario parte de una mirada desde el ámbito de la comunicación, dónde se estudia el impacto de los productos comunicativos en relación a sus audiencias y sus representaciones. Aquí cabe destacar la propuesta de Martín Barbero, la cual se centra en el poder de la audiencia y las "mediaciones." (Barbero, 1982, pág. 2) Otra línea de investigaciones especifica el rol de la prensa y la ética periodística. Estudios como los efectuados por Roger Simpson y William Cot (Simpson \& Cot, 2006, pág. 10) y Andrew Belsey y Ruth Chadwick (Belsey \& Chadwick, 1994, pág. 5) apuntan a la existencia de una base teórica de ética periodística, incluyendo códigos de conducta y principios de transparencia, 
relacionados tanto con el rol de las mujeres como con casos de criminología y violencia.

\subsection{Interaccionismo simbólico}

Bajo la óptica de Erving Goffman, el teórico más representativo del interaccionismo simbólico, en los encuentros sociales se construye, realiza y expresa el orden social. Por el término encuentro social se entiende una "ocasión de interacción cara-a-cara que comienza en la presencia inmediata de otros y que acaba cuando ellos captan que han salido de esta situación de participación recíproca." (Wolf, 1982, pág. 33) De igual manera, en su trabajo póstumo, Goffman desarrolla un interés notorio en las formas cómo la interacción social y sus rituales operan y se reproducen en medios como la radio, la televisión y la publicidad. El ritual deja de ser "un acto formal y convencionalizado a través del cual un individuo manifiesta su respeto y su consideración hacia un objeto de valor absoluto o hacia su representación." El ritual más bien es considerado como una serie de interacciones ejecutadas por individuos, o actores, que pueden incluso estar presentes en la vida cotidiana de las maneras más rutinarias. (Joseph, 1999, pág. 36)

¿Cómo se aplica el interaccionismo a los medios y a la cobertura de prensa? Goffman argumenta que el carácter dramatúrgico de las interacciones diarias se reproduce y acentúa por las interacciones de los medios de comunicación. Performances en la prensa, la radio y la televisión representan y amplifican los roles, convenciones y normas sociales familiares para sus audiencias, lo cual hace que actúen como formas de reproducir estereotipos. El primer acercamiento de Goffman a las formas de interacción de los medios es su análisis de las charlas en radio y televisión, a las cuales compara con conversaciones ordinarias que son interpretadas en situaciones de presencia física. Goffman hace particular énfasis en los locutores de radio y presentadores de noticias, que tienen el objetivo de producir un flujo de palabras de ilusión "espontánea”.

Esta relación dinámica entre actores "reales" e intérpretes de los medios se evidencia en un estudio de Goffman sobre la representación de género en la publicidad de revistas. Goffman se refiere a la publicidad como pantallas que proveen "términos de contacto entre los intérpretes de los medios y las personas que las perciben.” (Laughey, 2008, pág. 26) Los intérpretes y las audiencias construyen, de manera conjunta, el significado, ya sea cara-a-cara o en una situación mediatizada. Por ende, la publicidad, 
al igual que los demás medios de comunicación, posee un carácter dialógico. Aquel diálogo es un ritual de interacción social, que puede darse tanto en situaciones de presencia física como en situaciones otorgadas por los medios. La imagen corporal es un ejemplo claro de cómo se da el proceso de interacción, puesto que las innumerables imágenes de cuerpos idealizados sirven como un recurso, otorgado por los medios, para juzgar la idoneidad del self y de los demás. Esto contribuye, a su vez, a la elaboración de un amplio interés social en las dietas y el ejercicio como forma de vida. (Joseph, 1999, pág. 63)

Asimismo, las pantallas de los medios de comunicación, como las que presentan el concepto de género en publicidad impresa en revistas, tienden a reproducir imágenes convencionales de rituales de interacción en la vida social. Goffman argumenta que aquellas representaciones convencionales de género no son únicamente el producto de una representación mediática estereotipada, pero el resultado de una relación dinámica de interacciones sociales. Adicionalmente, los significados no son resultado de estructuras separadas en las fases de producción y recepción, como argumentan los teóricos estructuralistas, pero producidos en consecuencia de la interacción entre productores y audiencias. Como resultado, de acuerdo a la teoría de Goffman, no existen efectos mediáticos de estímulo-respuesta ni funciones ideológicas en los medios de comunicación. Las representaciones en los medios son reconstrucciones mediáticas que estandarizan, exageran y simplifican rituales de la cotidianeidad. Es así cómo los medios de comunicación representan una versión artificiosa de rituales sociales, normas y convenciones, como por ejemplo, la subordinación de la mujer frente al hombre, que existen en las situaciones sociales de la realidad. (Laughey, 2008, pág. 19) Aquel fenómeno es denominado por Goffman como "híper-ritualización", puesto que se convierten en rituales de formas de interacción ya existentes en el mundo social.

Igualmente, el trabajo de Goffman sobre el estigma es relevante. La definición clásica de estigma social describe al fenómeno como "un atributo profundamente desacreditador dentro de una interacción social particular", donde el individuo portador queda disminuido en su valor social en relación a los otros participantes de la interacción. (Goffman, 1995, pág. 3) El concepto puede ser ampliado para aplicarse al modo cómo un colectivo estigmatiza al otro. Por ejemplo, aplicado a una situación de 
género, el fenómeno implica las maneras cómo el género masculino puede estigmatizar al femenino. Se puede explorar la posibilidad de lidiar con el estigma como un medio de relación entre grupos sociales, donde existe una imposición de uno sobre otro y una aceptación de la expresión del poder, concretada en la estigmatización misma. Sin embargo, con frecuencia, el estigma es reducido a un sinónimo de discriminación o exclusión social. Esto crea la confusión, gracias a definiciones ambiguas, con fenómenos propios de la interacción humana como los estereotipos negativos. Una de las principales características del estigma social, que distingue al fenómeno de otros similares, es la reacción específica que puede desencadenar el atributo estigmatizante en una persona que no lo porta dentro de la interacción social. Aquello se reconoce como una sensación de incomodidad frente a la persona estigmatizada.

\subsection{La violencia, el género y la víctima}

La violencia es un problema sistémico y generalizado en toda sociedad y abarca tres elementos: el agresor, la víctima y la relación entre ambos. Aquellos tres conceptos sirven como "un buen punto de partida para analizar las causas y las razones de la violencia." El agresor es quien está en cierto grado motivado y dispuesto a agredir. Dentro del marco tradicional, se considera al agresor poseedor de una motivación antisocial, concretada en ciertas creencias, hábitos delictivos y explosiones de ira. Para concretar la conceptualización del rol de agresor, es necesaria la presencia de una víctima que suscite su interés. Asimismo, se requiere "una cierta desprotección de la víctima, que la pone en mayor riesgo de sufrir la agresión." (Echeburúa \& Redondo, 2010, pág. 31)

Respecto a la violencia de género, la perspectiva más tradicional es conocida como la perspectiva biológica, la cual busca ligar la violencia con la mayor fuerza física y a la mayor presencia de testosterona en el sexo masculino, que genera una mayor predisposición, en relación a las mujeres, a llevar a cabo delitos de índole violenta. (Echeburúa \& Redondo, 2010, pág. 54) Al atribuir aquellas propensiones a la agresión a la naturaleza biológica de cada género, se convierten en rasgos esencialmente inalterables.

El género como categoría de análisis se comprende como una "simbolización socio cultural cuya base de interpretación es la diferencia biológica, que determina una diferenciación de roles, sentidos, prácticas y relaciones de dominación”. Aquellas se 
reproducen mediante ideas, discursos y representaciones sociales, capaces de condicionar la conducta objetiva y subjetiva de las personas en función a su sexo. Bajo esta óptica, lo biológico pasa a un segundo plano frente a lo social, en determinación del comportamiento y patrones de conducta de los individuos. (Macassi, Meléndez, Rosas, \& Yáñez, 2010, pág. 22)

Es destacable que gran parte de la perpetuación de la violencia se da por hombres, independientemente del sexo y edad de la víctima; motivo por el cual la violencia masculina contra la mujer ha devenido un área de interés de investigación propio, como sostiene Mary Nash. (Velázquez, 2003, pág. 28) Sin embargo, en la mayoría de casos, ciertos tipos de violencia suelen ser "invisibles" o "naturales", legitimados en base a un discurso que opera gracias a la desigualdad de género y a la priorización de lo masculino. Esto conlleva a la justificación del accionar violento como forma habitual de relación entre ambos géneros, lo cual explica y excusa situaciones de violencia ejercida hacia la mujer como la violencia conyugal. (Fisas, 1998, pág. 42) Con el tiempo, el análisis de la violencia sexual ha desplazado su foco de interés desde el agresor hacia la víctima. La transición ha conllevado a la creación de un campo profesional y en creciente expansión agrupado bajo el término "victimología". El estudio de la víctima implica una serie de factores de vulnerabilidad que sirven con el fin de completar la comprensión de los hechos, como por ejemplo el atractivo sexual de la mujer agredida y su condición socioeconómica. No obstante, considerar estos factores involucra un proceso de desmitificación de las causas de la violencia sexista, reconociendo que, a pesar de que los factores pueden generar niveles diversos de vulnerabilidad, todas las mujeres están expuestas a situaciones de discriminación y "por lo tanto, pueden ser víctimas de violencia." (Macassi, Meléndez, Rosas, \& Yáñez, 2010, pág. 34).

\subsection{Estereotipos y discurso mediático}

Analizar la presencia de mitos y estereotipos en los medios es importante, puesto que las percepciones sociales sobre las mujeres son fabricadas, reproducidas y alteradas en aquellos espacios. De acuerdo al análisis crítico, es posible dividir los estereotipos mediáticos en dos categorías: positivos y negativos. El aspecto positivo de los estereotipos se da al proveer puntos de vista que permiten reconocer tipos de personajes e historias rápida y fácilmente. Aquello funciona porque, como 
consumidores de medios, los estereotipos actúan como una herramienta narrativa que ayuda al lector a descifrar el propósito de los mensajes dentro de un marco de tiempo y contexto predeterminado. (Goodall, 2012, pág. 161) Pero, los estereotipos también pueden tener un impacto negativo, porque tienden al prejuicio y actúan como obstáculos al uso del criterio racional de las audiencias y, además, son resistentes al cambio social.

A medida que se han diversificado y aterrizado los estudios, se ha concluido en la existencia de una distorsión respecto a la visión de la mujer en relación a la cobertura de casos de violencia sexual, que presenta a las víctimas de aquella violencia como “vírgenes”, “ángeles caídos” o "prostitutas”, según estudio de Helen Benedict. (Benedict, 1992, pág. 34) Las categorías sugieren que la inocencia de la víctima es asumida en ciertos casos, pero debe ser defendida constantemente para evitar caer bajo la etiqueta o categoría de "prostituta". En otras palabras, para evitar aquel calificativo, la violencia sexual no debe ser producto de la conducta seductora, vestimenta provocativa, pasado sexual o profesión de la víctima. De lo contrario, se culpabiliza a la víctima de la violencia sexual y la situación es utilizada como forma para advertir a otras mujeres contra aquellos tipos de comportamiento. (Fernández Díaz, 2003, pág. 40)

Adicionalmente, Benedict sostiene que los estereotipos que la prensa suministra sobre las mujeres en relación a la violencia sexual moldean una comprensión abstracta que reduce el fenómeno a sus componentes más superficiales y ligados a la apariencia. El cuerpo femenino, una vez reducido a su biología, se ve encadenado al estereotipo de la "pasividad", el cual remite a la sumisión y a la debilidad. (Benedict, 1992, pág. 12) Es así como los estereotipos que parten de una percepción negativa de la feminidad y de las mujeres reproducen una ideología que legitima ciertos tipos de crimen. El estereotipo de la "pasividad" hace de la mujer receptora de asaltos sexuales no deseados y el discurso culpabilizador nace como resultado de un abandono de aquellos cánones de la pasividad.

\subsection{Marco referencial}

Los delitos de violencia sexual son frecuentes en Latinoamérica y en el Perú. Un estudio efectuado por la Organización Mundial de Salud (OMS) en el año 2013 reveló que el Perú ocupa el tercer puesto a nivel mundial en frecuencia de casos de violencia sexual. Aquello corresponde a 17,763 denuncias anuales, de acuerdo a cifras 
del Ministerio Público. El Perú cuenta con las tasas de denuncias por violaciones sexuales más altas de la región, lo cual se perpetúa en distintos grupos de edad y sectores socioeconómicos. (OMS, 2013, pág. 3)

Sin embargo, las cifras respecto a casos de violencia sexual son dispersas y se encuentran desactualizadas, ya que las denuncias son atendidas por diversas dependencias. Por ejemplo, en el Perú, instituciones como la Policía Nacional, los Centros de Emergencia Mujer del Ministerio de la Mujer, el Instituto de Medicina Legal y el Ministerio Público registran las denuncias de manera aislada y sin exhaustividad de información (Mujica, 2011, pág. 14). Adicionalmente, no existen mecanismos precisos de recojo y sistematización de la información respecto a dichos casos, por lo que existe una "cifra oscura" de casos no contabilizados. Aquello no permite una medición precisa del fenómeno. Para ejemplificar, de manera análoga, solamente el 16\% de las víctimas de violencia familiar entre el 2004 y el 2009 hicieron la denuncia ante una institución del Estado. Sumado a ello, sólo un pequeño porcentaje de las denuncias que llegan a la Policía Nacional del Perú tienen una sentencia efectiva y condena en prisión. De las denuncias efectuadas por violación sexual ante la Policía, solamente un $62 \%$ ha implicado la detención del presunto perpetrador. (Mujica, 2011, pág. 23)

Es necesario señalar que el $93 \%$ de las víctimas de las denuncias por violación sexual, recibidas por la Policía Nacional entre el 2000 y 2009, son mujeres. Aquel porcentaje equivale a 58,874 denuncias. Aquí es preciso añadir que la mayor parte de las víctimas son menores de 18 años, de acuerdo a registros de la Policía Nacional del Perú. Esto corresponde a un $78 \%$ del total de denuncias, que protagonizan a víctimas menores de edad. En el Perú, Lima es la región del país que más denuncias concentra. Aquello se debe, en parte, al peso demográfico que tiene la capital en relación al resto del país. Para el 2011, Lima reportó el mayor número de denuncias, alcanzando un 38.4\% del total de denuncias. (Mujica, 2011, pág. 34).

La información de la Policía Nacional muestra que en más del 25\% del total de denuncias de violación sexual hay algún tipo de "relación directa" entre la víctima y el agresor. Aquel porcentaje corresponde a 33,486 denuncias efectuadas entre el 2000 y 2009. El término "relación directa" incluye solamente vínculos formalmente establecidos (como matrimonio, filiación y relación laboral) dejando de lado aquellos que no son estables (como amistad, enamoramiento, entre otros). Según el antropólogo 
Jaris Mujica, aquello genera un problema al momento de la recolección de la información en relación a esta variable, pues se suelen encontrar situaciones de amigos, conocidos o compañeros dentro de los casos que se encuentran bajo la categoría de "relación no directa". (Mujica, 2011, pág. 36) Según el Demus, un 42\% de casos denunciados suceden en los domicilios de la víctima y un $7,9 \%$ se dan por parte del esposo o pareja (INEI). (Demus, 2011, pág. 41)

\section{CAPÍTULO II: METODOLOGÍA}

El tipo de investigación es de análisis de contenido, puesto que permite investigar el discurso y analizar a profundidad el contenido de los materiales de comunicación. En este caso, se seleccionaron 23 notas informativas de prensa escrita en relación a casos de violencia sexual, que son organizadas y categorizadas según la información a investigar. Aquellas notas de prensa provienen de los siguientes cuatro diarios de Lima, Perú: El Comercio, La República, Trome y Correo. Aquellos diarios fueron elegidos al poseer líneas editoriales diversas, contar con variaciones en niveles de lectoría y apuntar a públicos objetivos diferentes. El Comercio corresponde a la categoría de diario de "prestigio", al ser el diario más importante del país y contar con un tiraje de 100,000 ejemplares diarios. La República, el principal competidor de El Comercio, tiene una orientación política de centro-izquierda y utiliza el formato berlinés. El diario Trome pertenece al Grupo El Comercio y apunta a un público objetivo de nivel socioeconómico $\mathrm{C} / \mathrm{D}$, utilizando un formato de tabloide y un lenguaje más coloquial. Es el diario más leído en Lima, de acuerdo a cifras del CPI. El Correo, por su parte, utiliza el formato de tabloide y es el sexto diario más leído en Lima, según CPI (Compañía Peruana de Estudios de Mercados y Opinión Pública, 2015).

Para identificar los casos de violencia sexual a utilizar en la muestra de la investigación, se recurrió en primera instancia a la página web de los cuatro diarios seleccionados (elcomercio.pe, trome.pe, larepublica.pe y diariocorreo.pe) con el objetivo de visualizar la cobertura de los casos de violencia sexual, viendo su frecuencia y periodicidad, al igual que detectar patrones que permitan seleccionar los casos que hayan tenido mayor exposición y cobertura en los cuatro diarios en los cuales se focaliza la investigación. Igualmente, utilizar los buscadores en línea, extrayendo palabras clave como "violencia sexual" o "violación" sirve para abreviar la búsqueda y 
hacer una exploración inicial, únicamente referencial. Aquello es debido a que el análisis de contenido es efectuado exclusivamente en base al contenido textual de las notas informativas de prensa en la versión impresa de dichos diarios.

Para hacer la muestra lo más representativa posible, los casos de violencia sexual son seleccionados en base a su ubicación temporal, repartidos en cuatro periodos de seis meses correspondientes a los últimos dos años (2013 y 2014). Para dotar de actualidad a la investigación, se ha incorporado un caso adicional perteneciente a los primeros seis meses del presente año (2015). Como criterio de selección, se han seleccionado casos que involucren como víctimas a mujeres adolescentes o jóvenes, excluyendo aquellos que involucren a niños, puesto que incluirlos en la muestra alteraría la naturaleza de los resultados al tratarse de otra categoría de violencia (abuso infantil). Igualmente, los casos seleccionados aparecen, como mínimo, en tres de los cuatro diarios correspondientes a la muestra. El criterio de selección se basa en escoger casos "emblemáticos", que hayan tenido una cobertura significativa en la muestra, ya que se apunta por analizar los casos más representativos dentro del periodo de tiempo investigado. De igual manera, aquello permite efectuar un análisis comparativo entre la cobertura en dichos diarios. Las notas informativas que hayan tenido una cobertura mínima, correspondiente a sólo uno o dos diarios de la muestra, no fueron incorporadas dentro de la investigación.

Las notas de prensa fueron recopiladas de las ediciones impresas de los periódicos, tomando como punto referencial las fechas en las versiones online, y, por prevención, se dejó un margen de $2( \pm)$ días, para encontrar con mayor fidelidad la cobertura real de la noticia en la versión impresa. Una vez recopiladas las notas informativas, el recojo de datos es sistematizado, digitalizando las notas de prensa y llenando cuadros que incluyen datos básicos sobre la muestra, al igual que los indicadores que permiten sustentar las variables observadas.

Para extraer los discursos presentes en la cobertura de prensa escrita en relación a casos de violencia sexual, se buscan indicadores correspondientes tanto a la presencia de mitos y estereotipos como al proceso de victimización. Los indicadores son extraídos llenando tablas que faciliten la agrupación de la información, tomando en cuenta un enfoque interdisciplinar y las dimensiones socioculturales propias del lenguaje y la comunicación. En lo relativo al primer eje sobre la presencia de mitos y 
estereotipos, se buscan indicadores referentes tanto al perfil de la víctima como al del agresor. Los indicadores a observar en el primer eje son: la ausencia de nominalización de la víctima y el agresor, la comparación, los recursos lingüísticos, la profundización de la información y la presentación misma del contenido. Por otro lado, los indicadores a tomar en cuenta respecto al segundo eje sobre el proceso de victimización, incluyendo el nivel de exposición mediática y la naturaleza de la cobertura periodística, son: la apropiación del léxico del discurso legal, el argumento exculpatorio, la jerarquización y la intensidad de difusión del tema.

\section{Indicadores seleccionados:}

\section{Ausencia de nominalización de víctima y agresor:}

No hacer referencia al nombre tanto de la víctima como del agresor. Utilización y precisión de un rasgo diferenciador (como por ejemplo, etnia o clase social). Funcionalización (referencia al agresor por su estatus o profesión). Perífrasis neutralizante (referirse al agresor como el "autor de"). Neutralización (referirse al agresor como "persona"). Caracterización criminal (ej. asociaciones con desórdenes patológicos).

\section{Comparación}

Generalizaciones, exclusiones, eufemismos, perífrasis, negaciones, polarizaciones y contrastes.

\section{Recursos lingüísticos}

Recursos de sustitución (la metáfora), recursos de adición (pleonasmo), metonimia.

\section{Profundización de información}

Nivel de detalles y empleo de adjetivos.

\section{Presentación del contenido:}

Incluye elementos formales de la nota de prensa como titulares, bajadas voladas y lead. Unidad de registro: frases y párrafos. Unidad de contexto: autor, fecha, diario de origen

\section{Apropiación de léxico del discurso legal}

Incluye el empleo de términos como "acusado", "procesado", "encausado."

\section{Argumento exculpatorio}

El empleo de la presunción de inocencia del agresor en relación al juicio mediático. 


\section{Jerarquización}

Referirse al agresor bajo el término de "acosador", situado por encima de la víctima en un plano jerárquico de poder.

\section{Intensidad de difusión del tema}

Frecuencia de inclusión del tema de violencia sexual en los diarios analizados.

\section{Presentación del contenido:}

Incluye elementos formales de la nota de prensa como titulares, bajadas voladas y lead. Unidad de registro: frases y párrafos. Unidad de contexto: autor, fecha, diario de origen

\section{CAPÍTULO III: RESULTADOS}

De los 23 casos de violencia sexual analizados, ninguno logra una cobertura en portada y, más bien, las notas de prensa sobre aquel tipo de delitos suelen tener una cobertura limitada, puesto que tienen una extensión reducida en secciones secundarias que tiende únicamente a incluir los datos más básicos e informativos. Por lo general, no hay una incidencia en detalles ni una reconstrucción narrativa y minuciosamente descriptiva de los hechos que haga uso de recursos lingüísticos como, por ejemplo, metáforas e hipérbole. No obstante, si bien la redacción no aparenta contar una historia, la noticia se da en base a narrar la interacción entre dos actores clave: el agresor y la víctima. Incluso, el relato noticioso se amplía en algunas instancias para incluir a otras figuras secundarias, como la policía o el poder judicial, que alimentan el contenido discursivo de la nota informativa.

\subsection{Mitos y estereotipos}

En relación a los indicadores analizados, predomina una ausencia de la nominalizacion de tanto la víctima como el agresor, ya que ambos suelen ser referidos en base a atributos o características particulares que los describen e identifican. La funcionalización es el hacer referencia al agresor en base a su profesión, estatus u ocupación, y está presente de manera mayoritaria dentro de la muestra estudiada. Aquello puede ser debido a que las notas de prensa de violencia sexual con mayor cobertura suelen incluir figuras políticas o ex funcionarios políticos, motivo por el cual su profesión cobra mayor protagonismo dentro del relato noticioso. Además, el escándalo inherente en este tipo de casos, debido a la calidad de "figura pública" de sus 
protagonistas, hace de la noticia una de mayor atractivo e interés para la audiencia. Es así cómo "la saliente máxima autoridad" (El Comercio, 6 de enero del 2015) o "el ex funcionario regional" (La República, 8 de enero del 2015) son términos comunes para hacer referencia a los agresores de la violencia sexual de acuerdo a los casos seleccionados. Por otro lado, la funcionalización también se hace presente instancias en las cuales el agresor no está vinculado a la esfera política y, es en dichos casos, que se busca tácitamente asociar al agresor con el "Otro", ya que buscan minimizarlo o restarle validez al referirse a éste en base a ocupaciones de reducido prestigio, como "delincuentes comunes" (El Comercio, 18 de febrero del 2013) o como un "falso promotor de eventos" (Trome, 14 de enero del 2014). Este tipo de narración incluye una estrategia de distanciamiento en la cual se busca alejar a la alteridad; es decir, el agresor.

Si bien no hay una caracterización criminal propiamente delimitada ni una asociación explícita con trastornos patológicos en lo referente al agresor, existe una caracterización que lo asocia con conductas socialmente inaceptables y que define un comportamiento anormal, antosocial y patológico. El agresor "amenazaba con publicar las imágenes en YouTube si no accedían a sus requerimientos sexuales..." (Trome, 14 de enero del 2014) o "la acosaba con mensajes de texto obscenos e incluso la amenazaba de muerte" (Correo, 16 de julio del 2014). Dicho comportamiento anómalo acompaña acciones que narran posteriormente los sucesos de violencia sexual, como "luego, uno de los hampones procedió a ultrajar a la turista." (La República, 16 de febrero del 2013) Aquello busca indirectamente sugerir una causalidad entre los trastornos del agresor con sus tendencias criminalísticas de violencia sexual, aludiendo al hecho de que se trata de un tipo de crimen propagado por un sujeto con patologías. El estereotipo del agresor como "acosador" recibe un tratamiento de "criminal" en los medios, en el cual se hace un acercamiento psicológico de su perfil y se incide en las maneras cómo su comportamiento es una desviación y un atentado contra la racionalidad, con el fin de generar miedo y malestar en el lector.

El agresor siempre es claramente identificado en base a su nombre y apellido en las notas de prensa estudiadas. Para citar un ejemplo, "Julio César Chávez Pachas, de 30 años" (El Comercio, 14 de enero del 2014). Por contraste, existe una tendencia 
destacable a no hacer referencia al nombre de la víctima ${ }^{1}$, quien suele permanecer anónima o referida en base a una característica distintiva. La víctima pasa a ser "una de ellas" (Correo, 16 de febrero del 2013), "la jovencita" (Correo, 13 de octubre del 2013), "una joven de 19 años" (El Comercio, 13 de octubre del 2013) o una "chiquilla de 19 años" (Trome, 14 de enero del 2014) y su nombre suele ser omitido por completo de la nota informativa. Aquello se da incluso al tratarse de casos en los cuales la víctima en cuestión es mayor de edad $\mathrm{y}$, por consiguiente, casos en los cuales no hay una obligación legal de omitir el nombre ni proteger su identidad. La única excepción en la cual se incluye expresamente el nombre y apellido de la víctima es en el caso de la turista finlandesa, "Matilda Sara Vilheelmina Nordman Hognas" (Correo, 16 de febrero del 2013) y esto se replica en los cuatro diarios seleccionados para la muestra.

Si bien en algunas ocasiones el nombre de la víctima es omitido, los autores de las notas de prensa optan por incluir las iniciales del nombre o apellido de la víctima para hacer referencia a ésta sin necesidad de revelar su identidad por completo. Las iniciales suelen ser aplicadas para tanto el nombre como el apellido de la víctima y sus variaciones ("la joven B.R.L.S." (Trome, 14 de enero del 2014), la "menor de iniciales A.J.S.T" (Correo, 6 de enero del 2015)) o "Cindy A.J." (La República, 12 de octubre del 2013)). Aquello sirve como una manera de hacer que la víctima de la violencia sexual permanezca en anonimato y de proteger su identidad, quizás liberándola de repercusiones sociales y de un proceso de estigmatización.

Si bien se omiten datos claves como el nombre y el apellido de la víctima, el nivel de la profundización de la información narrada se hace notorio en ciertas instancias. Dicho recurso se hace presente a pesar del hecho de que la redacción es más informativa que descriptiva. Debido a ello, las instancias en las cuales es utilizado destaca dentro de la narración, que apunta a la objetividad y a la inclusión de datos concretos. Aquello es visible especialmente en la inserción de adjetivos o adverbios que tienden a la subjetividad o a la interpretación del redactor, quebrando drásticamente con el estilo objetivo e imparcial del resto de la redacción. Por ejemplo, el uso del pleonasmo "cobardemente ultrajada por un grupo de delincuentes armados" (El

${ }^{1}$ La omisión del nombre de la víctima se debe aplicar por ley en casos en los cuales la mujer agredida no es mayor de edad; es decir, mayor de 18 años. 
Comercio, 16 de febrero del 2013) indica un mayor nivel de atención al detalle y una estrategia para simpatizar con la víctima. Sucede del mismo modo con la "conducta deplorable" del agresor de la violencia sexual (Correo, 16 de julio del 2014). En ambos casos, el texto apunta a trastocar la pretendida objetividad del medio de comunicación, buscando alejarse de una racionalización del hecho.

Asimismo, un empleo mayor de adjetivos en incidentes no estrictamente vinculados a la violencia sexual en sí misma también se hace presente. Sucede en el caso en el cual “(Los manifestantes) no sólo bloquearon la vía, sino también destrozaron las oficinas y hasta cámaras de seguridad." (La República, 12 de octubre del 2013). El nivel de detalles en eventos complementarios desplaza el foco de la noticia hacia elementos secundarios, como la protesta de los vecinos, y lo aleja del incidente primario de violación sexual, mitigando la acción violenta al llevarla a un plano inferior de importancia frente a otros sucesos de menor gravedad.

También existe un nivel de precisión que se traduce en datos numéricos relativos a direcciones, horas del día o números de habitaciones de hotel. El agresor se encontraba "en la habitación 102 del hotel Mireya Rengifo" (Correo, 6 de enero del 2015), en "la calle José Bernardo Alcedo 218, habitación 512" (La República, 14 de enero del 2014) o "el 1 de enero, cerca de las 5:00pm" (El Comercio, 6 de enero del 2015). Los detalles en abundancia suelen especificar datos relativos al contexto, que ubican al lector en el tiempo y espacio del suceso. Aquello si bien aleja la narración del sensacionalismo y prioriza datos concretos, en el proceso absorbe otros datos de mayor magnitud y relevancia, como las repercusiones y efectos de la violencia sexual. Es excepcionalmente que se incide en detalles referentes a las secuelas fisiológicas del crimen o en los síntomas de la violencia sexual, como sucede con los "desgarros del origen sexual en la menor, así como restos de semen." (El Comercio, 8 de enero del 2015).

\subsection{Proceso de victimización}

En lo referente al proceso de victimización, predomina una apropiación del léxico del discurso legal que se hace presente en todos los casos analizados. Expresiones correspondientes al marco judicial para hacer referencia al agresor de la violencia sexual abundan, como lo es en el caso de "los acusados" (Correo, 13 de octubre del 2013), "el detenido" (El Comercio, 14 de enero del 2014) o "los 
inculpados" (La República, 6 de enero del 2015). Dichas expresiones son usadas al momento de informar sobre las decisiones tomadas por autoridades legales, como el juez, la fiscalía y la policía, quienes tienden a formar un rol protagónico en el relato noticioso como fuentes de información legítimas. De este modo, dichas figuras tienen un rol activo dentro de la nota informativa, puesto que dictaminan el nivel de culpabilidad y posibilidad de libertad de los "acusados", presentan las órdenes judiciales y ejecutan el allanamiento del domicilio de los "inculpados" (El Comercio, 13 de octubre del 2013). La presencia de autoridades judiciales en el relato, acompañadas del empleo del léxico legal, es un procedimiento de legitimación, por el hecho de que la presencia del juez actúa como una figura experta en dicha materia y como garante de opinión.

Sin embargo, se suele referir al agresor aplicando el léxico del discurso legal sin la necesidad de que haya un acompañamiento dentro de la nota informativa de las voces de autoridad legal o sin la necesidad de que se cubran los procesos judiciales mismos. Un ejemplo de ello se da en el diario El Comercio, donde se relata que "el detenido exigía a su víctima una cita a cambio de no publicar fotos íntimas." (El Comercio, 14 de enero del 2014) En dicho ejemplo, la narración gira en torno a una reconstrucción de los incidentes de la violencia sexual, más no incide en el aspecto judicial y, a pesar de ello, presta términos del discurso legal como "detenido".

Los puntos anteriores se vinculan íntimamente con la utilización recurrente del adjetivo "presunto", el cual asume la inocencia del agresor en casos en los cuales el delito no ha sido comprobado de manera oficial por una sentencia judicial. La presunción de la inocencia se manifiesta en diversas secciones de la nota informativa misma, incluso en los titulares ("Apresan a candidato al Gobierno Regional de Arequipa por presunta violación.” (El Comercio, 16 de julio del 2013)) o en los testimonios del agresor ("Aldázabal Soto, al momento de ser detenido, dijo ser inocente y que confía en la justicia" (Correo, 6 de enero del 2015)). Igualmente, el agresor es descrito como "presunto" en casi todas las instancias, como "presuntos violadores" (El Comercio, 13 de octubre del 2013) o como agresores que han sido "denunciados por el presunto delito de violación sexual” (La República, 16 de julio del 2015). Debido a ello, existe una tendencia demarcada por suponer o sospechar el acto de violencia sexual en cuestión, mas no de validarlo o confirmarlo en su totalidad. Dicho empleo va de 
acuerdo a la ley, según lo estipula la Constitución, la Convención Americana y el Código Procesal. ${ }^{2}$

Se podría añadir que el argumento exculpatorio se hace presente en la redacción misma, de manera implícita, en la forma cómo se estructura la nota informativa. Aquello sucede en el caso de una nota informativa en el diario Correo referente a un caso de violencia sexual por parte de un chofer y un cobrador. En este, se detalla que el "juzgado a cargo del caso señala que no tenía evidencias fehacientes, por falta de exámenes toxicológicos o indicios de inconsciencia." (Correo, 13 de octubre del 2013). Al incidir en la falta de resultados positivos de dichas pruebas empíricas, se le resta culpabilidad al agresor y se presume su inocencia, apropiándose nuevamente de un principio del discurso legal.

En lo relativo a la relación entre agresor y víctima, se plantea una jerarquización en la cual el agresor se sitúa en un plano de mayor poder y dominación. $\mathrm{Si}$ bien nunca se hace uso de términos como "acosador" para hacer referencia al agresor, se describen situaciones en las cuales éste hace uso de su masculinidad y mayor fortaleza física para situarse por encima de la víctima, demostrando dominio y supremacía. Para ejemplificar, se vuelve a repetir la figura de la extorsión. Esto se ve reflejado en el caso en el cual "los asaltantes los obligaron a tirarse al suelo y les robaron sus celulares, dinero en efectivo, tarjetas, cámaras fotográficas, entre otras pertenencias" (El Comercio, 16 de febrero del 2013) o el caso en el cual "sometieron a la menor a vejámenes sexuales en un hotel" (Correo, 8 de enero del 2015). Es en dichos ejemplos que el agresor es caracterizado en términos de su peligrosidad, puesto que es retratado como un sujeto incapaz de ejercer control total sobre sus propios actos y que actúa de un modo netamente instintivo y primario.

\footnotetext{
${ }^{2}$ Artículo II. Presunción de inocencia.
}

Toda persona imputada de la comisión de un hecho punible es considerada inocente, y debe ser tratada como tal, mientras no se demuestre lo contrario y se haya declarado su responsabilidad mediante sentencia firme debidamente motivada. Para estos efectos, se requiere de una suficiente actividad probatoria de cargo, obtenida y actuada con las debidas garantías procesales. En caso de duda sobre la responsabilidad penal debe resolverse a favor del imputado. 
De esta manera, se construye un perfil del agresor como un sujeto peligroso e impredecible, que contrasta fuertemente con la figura netamente pasiva e inactiva de la víctima femenina, quien tiende a ser sólo receptora de las acciones de su agresor o de fuerzas activas de terceros, como su familia. Esta última observación se visibiliza en casos en los cuales "los familiares y vecinos de la víctima irrumpieron ayer con palos y piedras en las oficinas de la empresa de transportes Nueva Era en Chosica" (El Comercio, 13 de octubre del 2013) o en los cuales "la familia de la jovencita de 19 años que habría sido ultrajada ayer por el chofer y cobrador de una coaster está preocupada" (Correo, 13 de octubre del 2013). La figura colectiva de la familia constituye un actor más activo e involucrado en el proceso de reivindicación del crimen que quien lo padece. Por consiguiente, si bien la mujer agredida siempre es anónima, la familia juega un rol más protagónico como agente de cambio que se indigna y busca el castigo o la justicia. Dentro de esta misma línea, en lo relativo a los procedimientos legales, las notas de prensa con frecuencia atribuyen el inicio del proceso judicial a la familia o a los padres. Por ejemplo, "la denuncia fue presentada por los familiares de la menor de iniciales A.J.S.T...” (Correo, 6 de enero del 2015) o, para citar otro, "Elmer Cáceres Llica, de 39 años, fue detenido ayer luego de que los padres de su supuesta enamorada, de 18 años, lo denunciaran por secuestro y violación.” (El Comercio, 16 de julio del 2014) Según este criterio, la inacción total de la víctima se ve camuflada por la toma de decisión de los padres, quienes dirigen el accionar de la mujer agredida.

Tomando lo anterior en consideración, se tiende a un reforzamiento de una dominación del elemento masculino, que identifica al varón como actante determinador y que contrasta con la mujer agredida, quien suele ser subordinada a objeto de la acción. En un caso en el diario El Comercio, se describe cómo "la víctima habría sido ultrajada y fotografiada desnuda por Chávez Pachas..." (El Comercio, 14 de enero del 2014). Bajo este óptica, el actor con agencia es el agresor y quien padece pasivamente los efectos de las acciones es la víctima. Las instancias en las cuales el relato se narra desde el punto de vista del accionar de la víctima constituyen una excepción. Entre éstas, cabe señalar un único caso proveniente del diario Correo, en el cual es la víctima "quien acusó a Cáceres de secuestrarla y ultrajarla sexualmente en su departamento..." (Correo, 16 de julio del 2014).

En términos de culpabilidad de la mujer agredida, los medios de prensa escrita tienden a optar por no incluir argumentos culpabilizadores, que atribuyan parte de la 
responsabilidad del crimen a la persona quien lo padece, al igual que juicios de valor. Por lo tanto, en una primera lectura de los casos seleccionados, no se responsabiliza a la víctima por el crimen que padece. Sin embargo, existe una notable excepción en el primer caso del año 2013, que concierne la violación de una turista finlandesa. En éste, se menciona cómo "los cuatro habían ido a Cerro Negro, pese a que se encuentra prohibido visitar esta zona por ser desolada y carecer de presencia policial." (El Comercio, 16 de febrero) La inclusión del hecho de tratarse de una zona alejada diluye la responsabilidad del agresor y la traslada parcialmente hacia la víctima. Asimismo, en otro caso proveniente del diario La República, se añade que "el líder del partido, Juan Sotomayor García, lamentó lo ocurrido e informó que la decisión la tomó el Comité Ejecutivo Nacional, ya que no admitirían postulantes que tengan algún tipo de denuncias." (La República, 16 de julio del 2014) El uso del verbo "lamentar" emite, de manera subrepticia, un juicio de valor, ya que es una forma simpatizante de hacer referencia al agresor, cuya trayectoria política y vida profesional se va a ver "lamentablemente" afectada por haber cometido un delito de violencia sexual.

\section{CONCLUSIONES}

Si bien el manejo del lenguaje y la comunicación respecto a casos de violencia sexual en prensa escrita reproduce y fomenta mitos y estereotipos, ¿cuáles son éstos y qué implicancias tienen? Igualmente, respecto al manejo del poder simbólico y al proceso de victimización, se traslucen relaciones desiguales de poder entre ambos sexos, evidenciando pautas identificadoras con el grupo dominante y que priorizan lo masculino por encima de lo femenino en base a modelos hegemónicos de género. En relación a ambos ejes explorados, los objetivos específicos fueron logrados, puesto que los resultados permiten esbozar conclusiones respecto al discurso mediático hallado en la muestra seleccionada.

Estudios de Erving Goffman concluyen que los medios de comunicación son pantallas de términos de contacto que plasman situaciones mediatizadas entre productor y audiencia. Tomando esto en consideración, ¿qué dicen las pantallas de la prensa escrita respecto a la violencia sexual? Es decir, ¿cuál es el discurso mediático presente? ¿Refleja este una subordinación de la mujer frente al hombre? La prensa escrita reproduce mitos y estereotipos, como argumenta Goffman, que se dan en base a la 
construcción del perfil de tanto la víctima como del agresor. En lo respecto a la tipología del agresor, los resultados demuestran que predomina el estereotipo del criminal patológico, que actúa de manera antisocial y anormal, como por ejemplo, enviando mensajes de texto acosadores a sus jóvenes víctimas. Dicho punto trata de retratar al agresor como portador de impulsos sexuales incontenibles, que debe ser estigmatizado por la sociedad.

¿Cuál es la relación entre la víctima y el agresor? En la mayoría de casos no hay un tipo de "relación directa" 3 con el perpetrador de la violencia sexual, como matrimonial o una relación laboral. La víctima y el agresor, en la mayoría de casos, no se conocen previamente al delito de violencia sexual, a pesar de que en algunas instancias las violaciones tengan por agresores a personajes pertenecientes a la esfera pública, como ex funcionarios políticos. Existen algunas excepciones en las cuales el agresor tiene una relación directa con la víctima y, es en dichas instancias, que vemos con mayor periodicidad la tipología del "jefe acosador". Aquello se ve expuesto en el caso correspondiente a enero del 2014, en el cual un agresor engaña a una joven con la promesa de convertirla en modelo, logrando dicho cometido falsamente haciéndose pasar por un potencial jefe. Similarmente sucede en el caso de enero del 2015, en el cual el ex presidente regional de Madre de Dios es detenido por el secuestro y violación sexual a una joven que trabajaba como empleada del hogar de su esposa. Este último ejemplo permite pensar que los agresores no necesariamente son desconocidos por la víctima y que, más bien, pueden hallarse dentro de sus círculos sociales.

Otro punto importante respecto a los mitos y estereotipos en torno al agresor está estrechamente vinculado con el nivel socioeconómico del victimario. El nivel socioeconómico del agresor es evidenciado por medio de la funcionalización, bajo la cual se refiere al agresor en base a su profesión, estatus u ocupación. Cuando el nivel sociocultural del victimario es más elevado, se integra como parte del "Nosotros" y se mantiene una redacción objetiva y metódica. Esto se manifiesta en los casos en los cuales los protagonistas de la violencia sexual pertenecen a la esfera política, como ex

${ }^{3}$ Por "relación directa" se entiende algún tipo de relación previa entre víctima y agresor. Relación directa jurídicamente excluye a enamorados o enamoradas debido a que "no mantienen vínculo jurídico, por afinidad, o consanguíneo con la víctima." 
alcaldes. Por contraste, en las instancias en las cuales los perpetradores del crimen son "cobradores", "choferes" o "delincuentes comunes", se exhiben estrategias de distanciamiento, bajo las cuales se busca denigrar, por medio del empleo de adjetivos, como "comunes", al agresor.

Respecto al planteamiento de la víctima en torno a los mitos y estereotipos, cabe notar que todas las víctimas afectadas en la muestra estudiada son mujeres, lo cual sucede siguiendo el mismo patrón estadístico reportado en denuncias policiales. De acuerdo a las investigaciones previas, existe una transición del foco desde el agresor hacia la víctima, que da pie a campos independientes de estudio como la "victimología". Sin embargo, los resultados de la investigación evidencian que la reconstrucción de los hechos en notas de prensa escrita aún se da desde el enfoque o punto de vista del agresor, mientras que la víctima yace en un plano secundario, de pasividad y anonimato, como receptores de un mecanismo recurrente de sometimiento.

El estereotipo que más resalta en torno a la víctima es el de la mujer como ser pasivo e indefenso, caracterizado únicamente como receptor de asaltos sexuales no deseados. La tipología de la víctima es el de una mujer desprotegida, vulnerable y constantemente en riesgo de padecer la violencia sexual en todo tipo de circunstancias cotidianas. Ya que los estereotipos suelen reducir el fenómeno a sus componentes más superficiales, tienden a tomar como punto de partida rasgos vinculados principalmente con el aspecto físico y corporal de la mujer. El tratamiento del cuerpo de la mujer agredida es uno que es caracterizado por su sumisión y debilidad y que no da indicios de resistencia alguna en ninguno de los casos analizados. Es notable una pasividad exagerada, bajo la cual la víctima es anónima, incluso referida en base a términos comunes como "jovencita" o "muchacha", y su testimonio irrelevante para la cobertura noticiosa y el juicio mediático. El testimonio de la víctima viene a ser reemplazado por voces autorizadas, típicamente masculinas, como miembros de su familia, los jueces del caso y la policía que investiga los sucesos. La pasividad exagerada, que es asociada implícitamente con la feminidad, es justamente la crítica principal del movimiento feminista radical, el cual argumenta que existe una propagación de la desigualdad de géneros al plasmar a la mujer en un rol de abatimiento.

Por su parte, el estereotipo de la mujer como prostituta, expuesto en el trabajo de investigación de Helen Benedict, no está presente en la muestra y, por ende, no se 
exhibe una dicotomía de virgen-prostituta en lo referente al tratamiento de la mujer agredida. En ninguna instancia se mencionan la conducta seductora, la vestimenta provocativa o el pasado sexual de la víctima como factores relevantes de mencionar dentro de la estructura del relato de prensa. En consecuencia, dichos datos no adquieren relevancia como elementos claves para tácitamente sugerir que la presencia de la seducción justifica la violencia sexual que es ejercida sobre ellas, evitando un discurso abiertamente culpabilizador. No obstante, de manera indirecta, en algunos casos analizados se detiene en detalles que ayudan a restarle la culpa al agresor y transferirla hacia la víctima, como en el caso de la violación sexual a una turista finlandesa, en el cual la narración periodística en el diario El Comercio hace una breve pausa para añadir que la víctima se encontraba en una zona alejada y no regulada por la policía.

En base al fenómeno de victimización, se podría sostener que existe una revictimización de la víctima por parte de la prensa escrita. Esto sucede en la medida en que se califica a la mujer agredida como "víctima" y continúa al legitimar su pasividad. Aquel proceso de re-victimización puede darse incluso a un mayor nivel de profundidad en el caso de atribuirle directa o indirectamente parte de la responsabilidad del crimen que padece, como ha sido evidenciado anteriormente. Del mismo modo, al reconstruirse los hechos desde una perspectiva judicial (que replica los procesos burocráticos e ineficientes de dicha institución legal) se reitera en los tediosos procesos judiciales en condiciones que no respetan la privacidad de la víctima.

Respecto al nivel de exposición mediática, es notable que la cobertura de casos de violencia sexual es mínima y, a primeros rasgos, genera la sensación de que se trata de un tipo de crimen poco habitual y de menor importancia, a pesar de que estadísticamente se pueda comprobar lo contrario. Aquí vale la pena detallar la paradoja que se genera respecto a la cobertura mediática. Si se opta por no cubrir dichos crímenes, se corre el riesgo de invisibilizarlos. Por el contrario, si la intensidad de la difusión es frecuente, existe el riesgo de normalizarlos o naturalizarlos dentro del discurso mediático.

Tomando en cuenta la mínima cobertura vista respecto a estos casos, la tendencia va más hacia una "invisibilización" del crimen, que pueda quizás explicarse por el carácter "no público" de las violaciones sexuales, que genera la percepción de que este delito sucede en menor medida a la real. Ya que la tendencia es hacia brindar 
una cobertura limitada sobre dichos casos, quizás la principal forma de representación de la violencia sexual en prensa limeña es por omisión. Es posible explicar la invisibilización que sucede en prensa en relación a casos de violencia sexual como producto de los procesos mismos de generación de las notas informativas. Un motivo que puede explicar dicha tendencia es que la principal fuente de los periodistas al redactar las notas informativas son los partes policiales, basados en las denuncias legales y, como explicitado anteriormente en el análisis de la situación, sólo un porcentaje reducido de casos de violencia sexual llegan al plano policial y legal y, un porcentaje aún menor, será recogido por los periodistas.

De los cuatro diarios seleccionados para la muestra, Trome y Correo tienden más hacia una narración policiaca y novelesca dentro de parámetros de cobertura netamente informativos, mientras que El Comercio y La República apuntan más hacia una pretendida objetividad y una línea más tradicional y conservadora de narración. No obstante, ¿cómo se resuelve la supuesta objetividad en los cuatro diarios? Si bien los cuatro diarios optan por una cobertura de los hechos más informativa que descriptiva, como anteriormente mencionado, la pretendida objetividad es inexistente, puesto que dentro del discurso mismo, existe un empleo de lenguaje que trasluce juicios de valor inherentes en los cuatro diarios de la muestra.

Respecto a las limitaciones de la investigación, en una primera instancia, se esperaba encontrar una cobertura con una difusión y frecuencia mayor a la encontrada, al igual que con una extensión de mayor profundidad y nivel de detalles. En cambio, los resultados exponen una cobertura sumamente limitada, con una extensión reducida y mínima, que dificulta el análisis, puesto que restringe el tamaño de la muestra de manera substancial. Otra limitación considerable fue el contenido mismo de los textos que, además de ser breves y concisos, incluyen una apropiación del léxico judicial, que quizás podría explicarse debido al hecho de que las notas de prensa suelen hallarse dentro de las secciones policiales. Aquello fue una limitante debido a que la investigación no incide en un manejo del discurso judicial ni en las normativas y precisiones legales alrededor de dichos delitos. Por ejemplo, dentro del marco legal, la violencia sexual constituye delito, exclusivamente si ha sido demarcada la presencia de la penetración. Aquello se toma en cuenta en el plano legal, más no necesariamente en la redacción periodística. 
La violencia sexual es un fenómeno extendido en el país y cabe señalar su importancia, puesto que aterriza en prácticas delictivas recurrentes y comunes que son, sin embargo, recogidas parcialmente por los medios de comunicación, como la prensa escrita y estudiadas tangencialmente por instituciones académicas. Por ende, es necesario realizar estudios vinculados a dicha temática, con el fin de esclarecer el panorama respecto a este tipo de violencia, al igual que otras formas y manifestaciones de ésta, que no necesariamente involucren violaciones sexuales. La prevalencia de la violencia sexual marca una situación estructural en donde se evidencia la situación de vulnerabilidad de las mujeres. Aquel tipo de violencia agrieta desde adentro nuestra sociedad y es en las víctimas que se plasma su brutal cotidianidad, naturalizada en un discurso que espera cierto tipo de comportamiento de personas que encajan dentro del perfil patológico del "agresor".

La cobertura de prensa escrita presenta una figura en la cual los casos de violencia sexual parten de emociones violentas, tendencias anti sociales e impulsos ocasionales por parte del victimario. Sin embargo, la realidad es que estos patrones de conducta se fundan en acciones cotidianas de menor gravedad, como insultos y comentarios sexistas, que suelen buscar su justificación en un discurso machista y en patrones socioculturales discriminatorios. Las manifestaciones de violencia no son ejercicios aislados, sino extensiones de dinámicas de relaciones violentas, que tienen el potencial de atacar la libertad de las personas en su faceta más íntima. Es importante una comprensión sobre el hecho que tenga en cuenta que las víctimas deben ser la prioridad en dichos casos. En consecuencia, los medios de comunicación deben buscar la estabilidad de la víctima y garantizar su derecho a la salud y al bienestar, evitando caer en un proceso de re-victimización.

Sería interesante abordar el mismo tema de investigación, pero especializado en los casos de violencia sexual que involucren a menores de edad, debido a que éstos reciben la misma, o inclusive una mayor, cantidad de cobertura periodística en prensa escrita peruana. Igualmente, sería interesante determinar de qué modo los resultados varían al tratarse de un perfil de víctima distinto, en el cual, para citar un ejemplo, se aplica por ley la obligación de omitir el nombre de la víctima en publicaciones de prensa, y del mismo modo, existen implicancias a tomar en cuenta como el considerable desequilibrio de fuerza física que da pie a una relación aún más asimétrica de poder entre víctima y agresor. 
Similarmente, otra línea de investigación interesante podría girar en torno a un análisis de contenido especializado en el léxico legal-judicial, tomando como punto de base la normativa legal-jurídica aplicada para casos de violaciones sexuales en el Perú. Se podría realizar una investigación que tenga como objetivo el brindar respuestas que expliquen el por qué el discurso mediático respecto a casos de violencia sexual tiene un contenido y una apropiación del léxico legal tan demarcada, quizás desde un enfoque de criminología y ética. Otra investigación que gire en base al mismo tema podría enfocarse en explicar las razones por las cuales existe una incidencia en detalles en lo relativo al lugar espacial. Aquello permitiría acceder a información más precisa sobre lo relativo al contexto temporal y espacial de la violencia sexual. 


\section{REFERENCIAS}

Araïna, N. (2012). Gender violence and the representation of sexual and affective relationships: reflections on cross-media research. Catalan Journal of Communication \& Cultural Studies.

Barbero, J. M. (1982). De los medios a las mediaciones, comunicación, cultura y hegemonía. Barcelona: Gustavo Gili.

Belsey, A., \& Chadwick, R. (1994). Ethical Issues in Journalism and the Media.

Benedict, H. (1992). Virgin or Vamp: How the Press Covers Sex Crimes. Nueva York: Oxford University Press.

Bonnes, S. M. (2010). Gender and racial stereotyping in rape coverage: An analysis of rape coverage in Grocott's Mail. Grahamstown: Rhodes University.

Bottaro, L. (2012). El estigma en las relaciones sociales entre "grupos divergentes". Investigación y reflexión en Ciencias Sociales.

Brennan, S. (2006). Keeping the "lady" in line: A media study of the date rape drug discourse. . British Columbia: Simon Fraser University.

Butler, J. (2006). Deshacer el género . Barcelona: Paidós.

Comas, D. (2012). Making women more visible in the news. Catalan Journal of Communication \& Cultural Studies.

Demus. (2011). Violencia en relaciones de Pareja: Una búsqueda en la Subjetividad de las Mujeres. Lima: Editorial E.I.R.L 
Echeburúa, E., \& Redondo, S. (2010). ¿Por qué víctima es femenino y agresor masculino? Madrid: Ediciones Pirámide.

Fernández Díaz, N. (2003). La violencia sexual y su representación en la prensa. Barcelona: Anthropos.

Fisas, V. (1998). El sexo de la violencia. Barcelona: Icaria.

Franklin, B. (1999). Social Policy, Media and Misrepresentation. Florence: Routledge.

García Muñoz, N., \& Martínez García, L. (2008). La recepción de la imagen de las mujeres en los medios: una aproximación cualitativa. Comunicación y Sociedad.

Goffman, E. (1995). Estigma : la identidad deteriorada. Buenos Aires: Amorrortu.

Goffman, E. (1997). La presentación de la persona en la vida cotidiana. Buenos Aires: Amorrortu Ediciones.

Goodall, H. (2012). Media's Influence on Gender Stereotypes. Media Asia.

Harrington, C. (2010). Politicization of Sexual Violence : From Abolitionism to Peacekeeping . Surrey: Ashgate Publishing Group.

Hercovich, I. (1997). El enigma sexual de la violencia. Buenos Aires: Biblos.

Humphries, D. (2009). Women, Violence, and the Media: Readings in Feminist Criminology. Hanover: Northeastern University Press. 
Jankey, O. M. (2009). "Passion killings": A media and cultural perspective of intimate femicide in Botswana. Utah: University of Utah.

Joseph, I. (1999). Erving Goffman y la microsociología. Barcelona: Editorial Gedisa.

Laughey, D. (2008). Key Themes in Media Theory. Buckingham: Open University Press.

Macassi, I., Meléndez, L., Rosas, C., \& Yáñez, G. (2010). Entre luces y sombras: caminos para acceder a la justicia. Lima: Flora Tristán.

Marrero-Guillamón, I. (2012). Descentrar el sujeto: Erving Goffman y la teorización del sujeto. Revista Internacional de Sociología.

McCoy, V. (2004). The effect of language used in newspaper report of rape: Measuring readers' judgment of victim blame. Tulsa: University of Tulsa.

Mujica., J. (2011). Violaciones sexuales en el Perú 2000-2009. Un informe sobre el estado de la situación. Lima: Centro de Promoción y Defensa de los Derechos Sexuales y Reproductivos (PROMSEX).

Munévar M., D. I. (2012). Delito de femicidio. Muerte violenta de mujeres por razones de género. Revista Estudios Socio-Jurídicos.

O.M.S. (2013). Comprender y abordar la violencia contra las mujeres. http://apps.who.int/iris/bitstream/10665/98821/1/WHO_RHR_12.37_spa.pdf

O'Toole, L., Schiffman, J., \& Edwards, M. (2007). Gender Violence : Interdisciplinary Perspectives (2nd Edition). Nueva York: New York University Press (NYU Press). 
Salazar Burgos, P. G. (2011). "El espectáculo de la noticia". Lima: Universidad de Lima.

Sánchez Leyva, M. J. (2007). Crítica feminista y comunicación. Sevilla: Comunicación Social.

Simpson, R., \& Cot, W. (2006). Covering Violence : A Guide to Ethical Reporting about Victims and Trauma. Nueva York: Columbia University Press.

Sorensen, T. (2011). Compromised Masculinities: Issues Surrounding Rape and Sexual Torture of Men in Conflict Situations. Winnipeg: University of Manitoba.

Velázquez, S. (2003). Violencias cotidianas, violencia de género. Buenos Aires: Editorial Paidós.

Wolf, M. (1982). Sociologías de la vida cotidiana. Madrid: Ediciones Cátedra. 


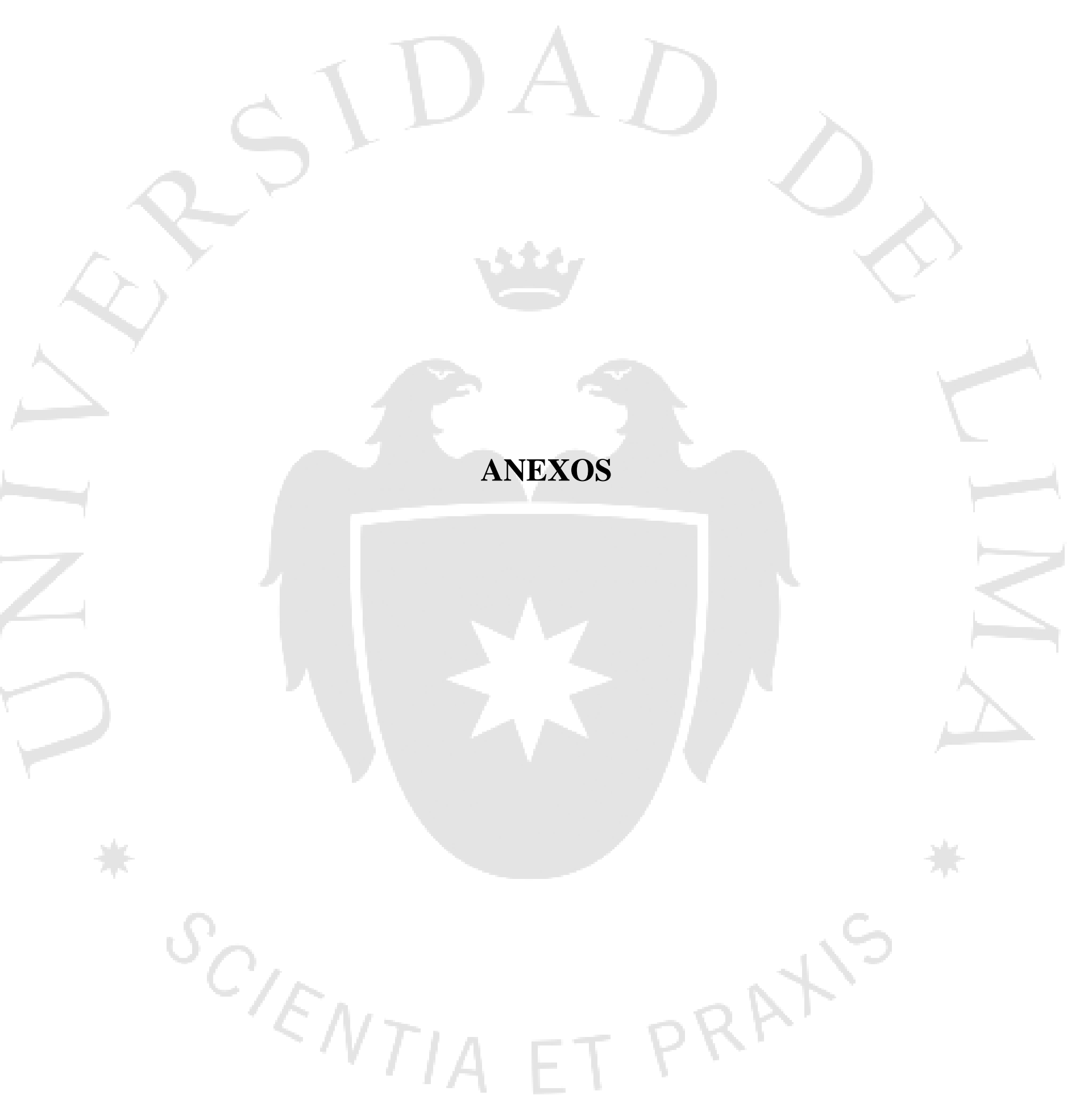




\section{ANEXO 1: Sinopsis de casos}

\section{Turista finlandesa es violada sexualmente en Trujillo (Febrero del 2013)}

Matilda Sara Vilhelmina Nordman, una turista finlandesa, fue robada y ultrajada sexualmente en Cerro Negro, en el distrito de Moche, por cinco delincuentes armados. La joven se encontraba acompañada por una compatriota finlandesa y dos compañeros peruanos al momento del crimen. Los asaltantes, además de utrajarla, robaron sus celulares, efectivo, tarjetas y cámaras fotográficas. Agentes de la División de la Policía de Turismo de Trujillo declararon que el certificado médico confirmaba que la turista había sido violada sexualmente por los ladrones.

\section{Dejan en libertad a dos presuntos violadores de joven (Octubre del 2013)}

Roberto Vidal Carrasco Alfaro y Christian César Navarro Palomino, chofer y cobrador de una coaster de la empresa Nueva Era, fueron acusados de violar a una joven de 19 años. La joven fue encontrada por oficiales de la PNP desnuda dentro del vehículo. El juez Omar Ahomed Chávez dictaminó la libertad de los dos acusados al no contar con suficientes pruebas para encarcelarlos. No obstante, la fiscalía consideró que sí hay pruebas concretas que justifiquen su captura. Los familiares y vecinos de la víctima protestaron, irrumpiendo con palos y piedras en las oficinas de la empresa Nueva Era, obstruyendo la Carretera Central y destrozando cámaras de seguridad.

\section{Violador engaña a joven con promesa de convertirla en modelo (Enero del} 2014)

Julio César Chávez Pachas fue capturado por la policía por extorsionar a una joven de 19 años a través de Facebook. Él la habría forzado a tener relaciones sexuales, extorsionándola con unas fotografías desnudas que le tomó en el año 2011. Dichas fotografías fueron tomadas bajo el engaño de que Chávez Pachas las usaría para impulsar la carrera de modelaje de la joven. Él la citó en un hotel en Lince y, al ingresar al hotel, fue detenido por oficiales de la PNP. Durante la intervención, le incautaron marihuana y una laptop con fotografías y grabaciones de menores y adultos, 
quiénes podrían ser sus víctimas.

4. Candidato a la alcaldía de Arequipa es acusado de violación sexual (Julio del 2014)

Elmer Cáceres Llica, candidato a la presidencia del Gobierno Regional de Arequipa por Vamos Perú, fue detenido por una denuncia de secuestro y violación hecha por su supuesta enamorada de 18 años. El suceso se realizó en el departamento de Cáceres Llica en el distrito de Cerro Colorado. Cáceres Llica y la joven se habrían conocido en una reunión del partido político Vamos Perú. En consecuencia, Vamos Perú optó por separarlo de sus filas y anuló su candidatura, puesto que no admiten postulantes con denuncias judiciales.

\section{Detienen a ex presidente regional de Madre de Dios por acusación de} violación sexual (Enero del 2015)

Jorge Aldazábal Soto, pediatra y ex presidente regional de Madre de Dios, fue detenido junto a su esposa Mireya Rengifo Velarde por un delito de secuestro y violación sexual a una joven de 16 años, quien trabajaba como empleada del hogar de Rengifo. La denuncia fue presentada por los padres de la menor, quienes indicaron que el delito sucedió en una habitación en un hotel de Puerto Maldonado el 1 de enero del 2015. Las evaluaciones médicas legistas concluyeron que la joven había sido efectivamente violada.

\section{ANEXO 2: Cuadro de diseño metodológico}

\begin{tabular}{|c|c|c|c|c|}
\hline $\begin{array}{l}\text { Unidades de } \\
\text { análisis }\end{array}$ & Variables & Indicadores & Herramientas & Muestra \\
\hline \multirow{3}{*}{$\begin{array}{c}\text { Discursos } \\
\text { presentes en la } \\
\text { cobertura de } \\
\text { prensa escrita } \\
\text { en relación a } \\
\text { casos de } \\
\text { violencia }\end{array}$} & \multirow{3}{*}{$\begin{array}{l}\text { Presencia de } \\
\text { mitos y } \\
\text { estereotipos }\end{array}$} & $\begin{array}{c}\text { Ausencia de } \\
\text { nominalización } \\
\text { de víctima y } \\
\text { agresor }\end{array}$ & \multirow{3}{*}{$\begin{array}{l}\text { Texto } \\
\text { periodístico- } \\
\text { análisis de } \\
\text { contenidos }\end{array}$} & \multirow{3}{*}{$\begin{array}{c}23 \text { notas } \\
\text { informativas de } \\
\text { prensa - } \\
\text { Coyuntura } \\
\text { significativa } \\
\text { Diarios: } \\
\text { El Comercio }\end{array}$} \\
\hline & & Comparación & & \\
\hline & & $\begin{array}{c}\text { Recursos } \\
\text { lingüísticos }\end{array}$ & & \\
\hline
\end{tabular}




\begin{tabular}{|c|c|c|c|}
\hline \multirow{7}{*}{$\begin{array}{c}\text { sexual } \\
\text { extraídos de } \\
\text { periódicos en } \\
\text { el Perú }\end{array}$} & & $\begin{array}{l}\text { Profundización } \\
\text { de información }\end{array}$ & \multirow[t]{7}{*}{$\begin{array}{c}\text { La República } \\
\text { Trome } \\
\text { Correo }\end{array}$} \\
\hline & & $\begin{array}{l}\text { Presentación } \\
\text { del contenido }\end{array}$ & \\
\hline & \multirow{5}{*}{$\begin{array}{l}\text { Proceso de } \\
\text { victimización }\end{array}$} & $\begin{array}{c}\text { Apropiación de } \\
\text { léxico del } \\
\text { discurso legal } \\
\end{array}$ & \\
\hline & & $\begin{array}{l}\text { Argumento } \\
\text { exculpatorio }\end{array}$ & \\
\hline & & Jerarquización & \\
\hline & & $\begin{array}{c}\text { Intensidad de } \\
\text { difusión del } \\
\text { tema }\end{array}$ & \\
\hline & & $\begin{array}{l}\text { Presentación } \\
\text { del contenido }\end{array}$ & \\
\hline
\end{tabular}

ANEXO 3: Cuadros de recojo de información

Cuadro 1.1: Caso 1 - Turista finlandesa es violada sexualmente en Trujillo

\begin{tabular}{|l|c|c|c|c|c|c|c|c|}
\hline \multicolumn{1}{|c|}{ Diario } & $\mathbf{N}^{\mathbf{0}}$ & Fecha & Titular & $\begin{array}{l}\text { Volada/ } \\
\text { Bajada }\end{array}$ & Sección & Página & $\begin{array}{c}\mathbf{N}^{\mathbf{0}} \text { de } \\
\text { párrafos }\end{array}$ & Fotos \\
\hline \multirow{2}{*}{$\begin{array}{l}\text { El } \\
\text { Comercio }\end{array}$} & $16 / 02 / 13$ & $\begin{array}{l}\text { Asaltantes } \\
\text { ultrajan a } \\
\text { turista } \\
\text { finlandesa } \\
\text { cerca de } \\
\text { Trujillo }\end{array}$ \\
\cline { 2 - 8 } & 2 & $18 / 02 / 13$ & $\begin{array}{l}\text { PNP } \\
\text { identifica } \\
\text { a dos } \\
\text { sujetos } \\
\text { que } \\
\text { violaron a } \\
\text { finlandesa }\end{array}$ & - & Regiones & A21 & 8 & 0 \\
\hline Trome & 3 & - & $\begin{array}{l}\text { Regiones } \\
\text { cobertura }\end{array}$ & A12 & 7 & 0 \\
\hline
\end{tabular}




\begin{tabular}{|c|c|c|c|c|c|c|c|c|}
\hline $\begin{array}{l}\text { La } \\
\text { República }\end{array}$ & 4 & ( & $\begin{array}{l}\text { Roban y } \\
\text { violan a } \\
\text { una } \\
\text { turista } \\
\text { finlandesa } \\
\text { en } \\
\text { Trujillo }\end{array}$ & - & Sociedad & 20 & 2 & 0 \\
\hline Correo & 5 & $16 / 02 / 13$ & $\begin{array}{l}\text { Asaltan y } \\
\text { violan a } \\
\text { turista de } \\
\text { Finlandia } \\
\text { en } \\
\text { campiña }\end{array}$ & - & Perú 360 & 6 & 1 & 1 \\
\hline
\end{tabular}

Cuadro 1.2: Caso 2 - Dejan en libertad a dos presuntos violadores de joven

\begin{tabular}{|c|c|c|c|c|c|c|c|c|}
\hline Diario & $\mathbf{N}^{\mathbf{o}}$ & Fecha & Titular & $\begin{array}{l}\text { Volada/ } \\
\text { Bajada }\end{array}$ & Sección & Página & $\begin{array}{c}\mathrm{N}^{\circ} \text { de } \\
\text { párrafos }\end{array}$ & Fotos \\
\hline $\begin{array}{l}\text { El } \\
\text { Comerci } \\
\text { o }\end{array}$ & 1 & $12 / 10 / 13$ & $\begin{array}{l}\text { Fiscalía } \\
\text { vuelve a } \\
\text { pedir } \\
\text { captura } \\
\text { de } \\
\text { acusados } \\
\text { de } \\
\text { ultrajar a } \\
\text { joven }\end{array}$ & & Lima & A13 & 6 & 0 \\
\hline \multirow{3}{*}{ Trome } & 2 & 09/10/13 & $\begin{array}{l}\text { Chofer y } \\
\text { cobrador } \\
\text { violan a } \\
\text { pasajera }\end{array}$ & $\begin{array}{l}\text { Volada. } \\
\text { En } \\
\text { Santa } \\
\text { Anita }\end{array}$ & Actualidad & 4 & 3 & 6 \\
\hline & & $10 / 10 / 13$ & $\begin{array}{l}\text { Chofer y } \\
\text { cobrador } \\
\text { violadore } \\
\text { s a la } \\
\text { fiscalía }\end{array}$ & $\begin{array}{l}\text { Volada. } \\
\text { Policía } \\
\text { compro } \\
\text { bó el } \\
\text { delito }\end{array}$ & Actualidad & 4 & 1 & 3 \\
\hline & 4 & $12 / 10 / 13$ & $\begin{array}{l}\text { Escándal } \\
\text { o por } \\
\text { violación } \\
\text { de chica }\end{array}$ & $\begin{array}{l}\text { Volada. } \\
\text { Implica } \\
\text { dos se } \\
\text { defiende } \\
\text { n }\end{array}$ & Actualidad & 10 & 4 & 5 \\
\hline
\end{tabular}




\begin{tabular}{|c|c|c|c|c|c|c|c|c|}
\hline & 5 & $13 / 10 / 13$ & $\begin{array}{l}\text { Me } \\
\text { desperté } \\
\text { y estaba } \\
\text { sin ropa }\end{array}$ & $\begin{array}{l}\text { Volada. } \\
\text { Relata } \\
\text { chica } \\
\text { víctima } \\
\text { de } \\
\text { violació } \\
\text { n }\end{array}$ & Actualidad & 10 & 3 & 3 \\
\hline $\begin{array}{l}\text { La } \\
\text { Repúblic } \\
\text { a }\end{array}$ & 6 & $12 / 10 / 13$ & $\begin{array}{l}\text { Protestan } \\
\text { por } \\
\text { liberación } \\
\text { de dos } \\
\text { presuntos } \\
\text { violadore } \\
\text { s }\end{array}$ & 38 & Sociedad & 20 & 3 & 1 \\
\hline Correo & 7 & 13/10/13 & $\begin{array}{l}\text { Hay } \\
\text { pruebas } \\
\text { contra } \\
\text { chofer y } \\
\text { cobrador }\end{array}$ & $\begin{array}{l}\text { Volada. } \\
\text { Habrían } \\
\text { violado } \\
\text { a joven } \\
\text { en una } \\
\text { coaster }\end{array}$ & Ciudad & 4 & $\square$ & \\
\hline
\end{tabular}

Cuadro 1.3: Caso 3 - Violador engaña a joven con promesa de convertirla en modelo

\begin{tabular}{|c|c|c|c|c|c|c|c|c|}
\hline Diario & $\mathbf{N}^{\mathbf{o}}$ & Fecha & Titular & $\begin{array}{l}\text { Volada/ } \\
\text { Bajada }\end{array}$ & Sección & Página & $\begin{array}{c}\mathbf{N}^{\mathbf{0}} \text { de } \\
\text { párrafos }\end{array}$ & Fotos \\
\hline El Comercid & 1 & $14 / 01 / 14$ & $\begin{array}{l}\text { Capturan } \\
\text { a un } \\
\text { sujeto } \\
\text { que } \\
\text { extorsion } \\
\text { aba a } \\
\text { joven por } \\
\text { Facebook }\end{array}$ & $\begin{array}{l}\text { Bajada. } \\
\text { El } \\
\text { detenido } \\
\text { exigía a } \\
\text { su } \\
\text { víctima } \\
\text { una cita } \\
\text { a } \\
\text { cambio } \\
\text { de no } \\
\text { publicar } \\
\text { fotos } \\
\text { íntimas. } \\
\text { Tambié } \\
\text { n es } \\
\text { acusado } \\
\text { de }\end{array}$ & Lima & A6 & 6 & 1 \\
\hline
\end{tabular}




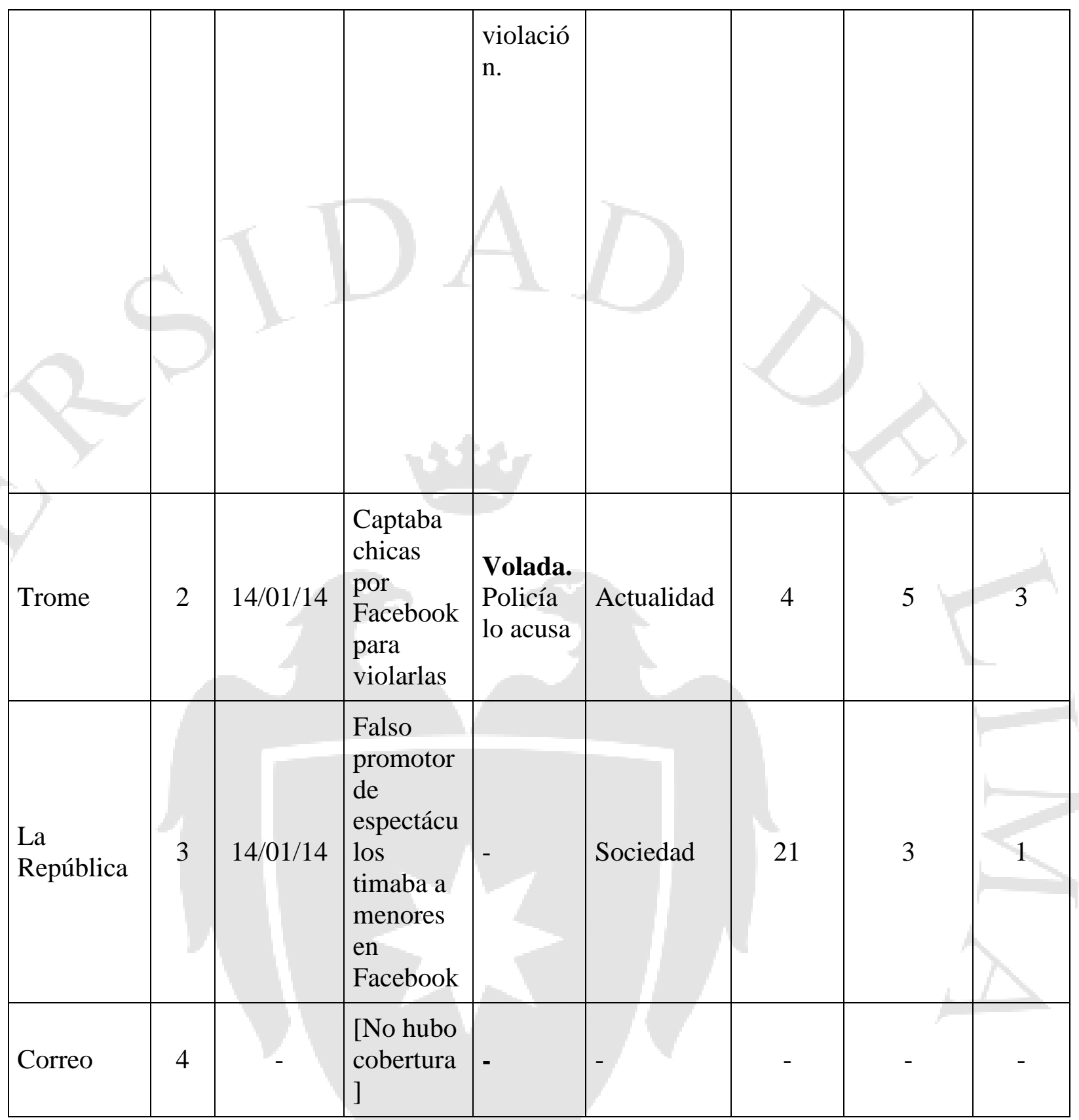

Cuadro 1.4: Caso 4 - Candidato a la alcaldía de Arequipa es acusado de violación sexual

\begin{tabular}{|c|c|c|c|c|c|c|c|c|}
\hline Diario & $\mathbf{N}^{\mathbf{0}}$ & Fecha & Titular & $\begin{array}{l}\text { Volada/ } \\
\text { Bajada }\end{array}$ & Sección & Página & $\begin{array}{c}\mathbf{N}^{\mathbf{0}} \text { de } \\
\text { párrafos }\end{array}$ & Fotos \\
\hline
\end{tabular}




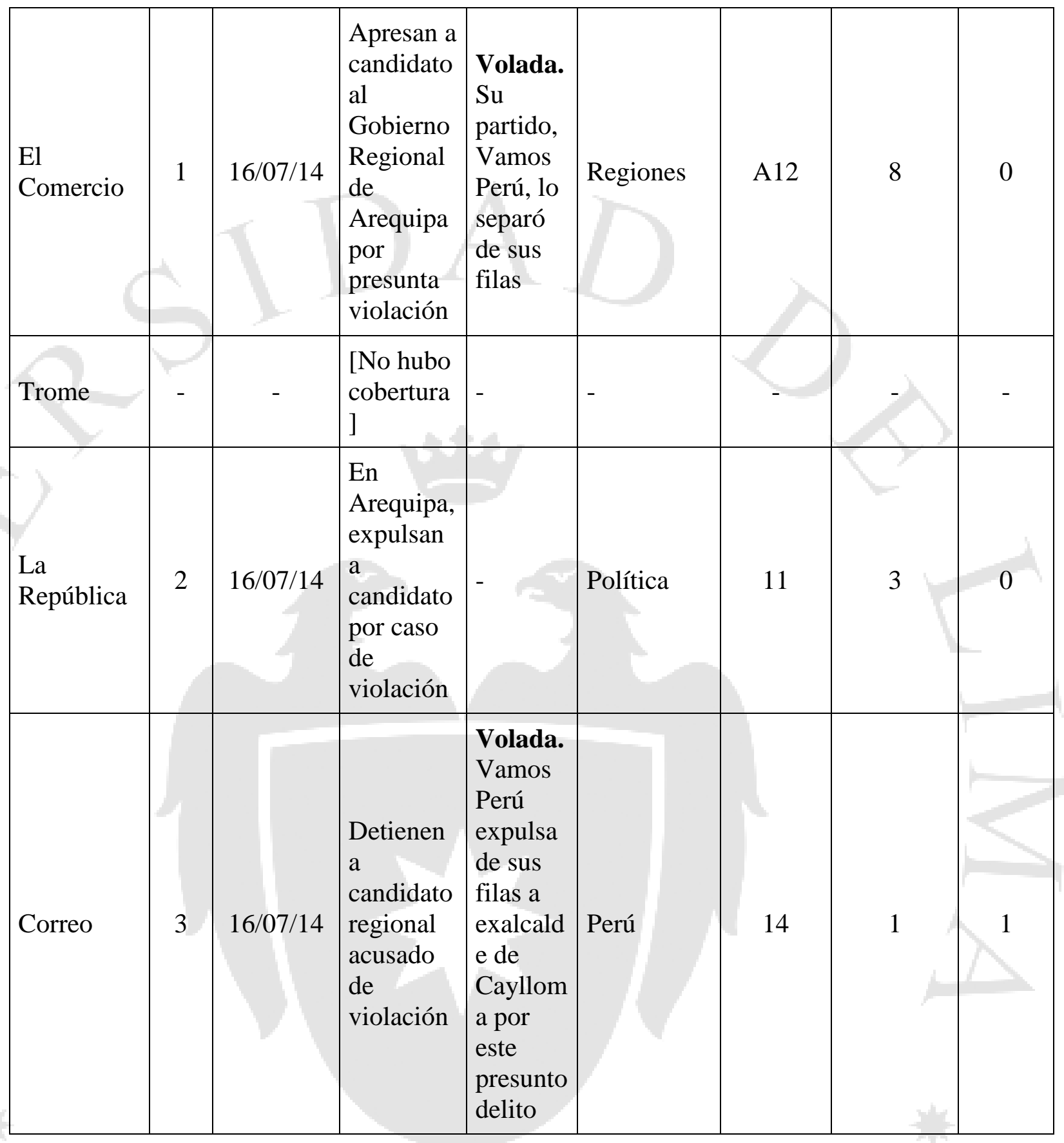

Cuadro 1.5: Caso 5 - Detienen a ex presidente regional de Madre de Dios por acusación de violación sexual

\begin{tabular}{|c|c|c|c|c|c|c|c|c|}
\hline Diario & $\mathbf{N}^{\mathbf{0}}$ & Fecha & Titular & $\begin{array}{l}\text { Volada/ } \\
\text { Bajada }\end{array}$ & Sección & Página & $\begin{array}{c}\mathbf{N}^{\mathbf{0}} \text { de } \\
\text { párrafos }\end{array}$ & Fotos \\
\hline
\end{tabular}




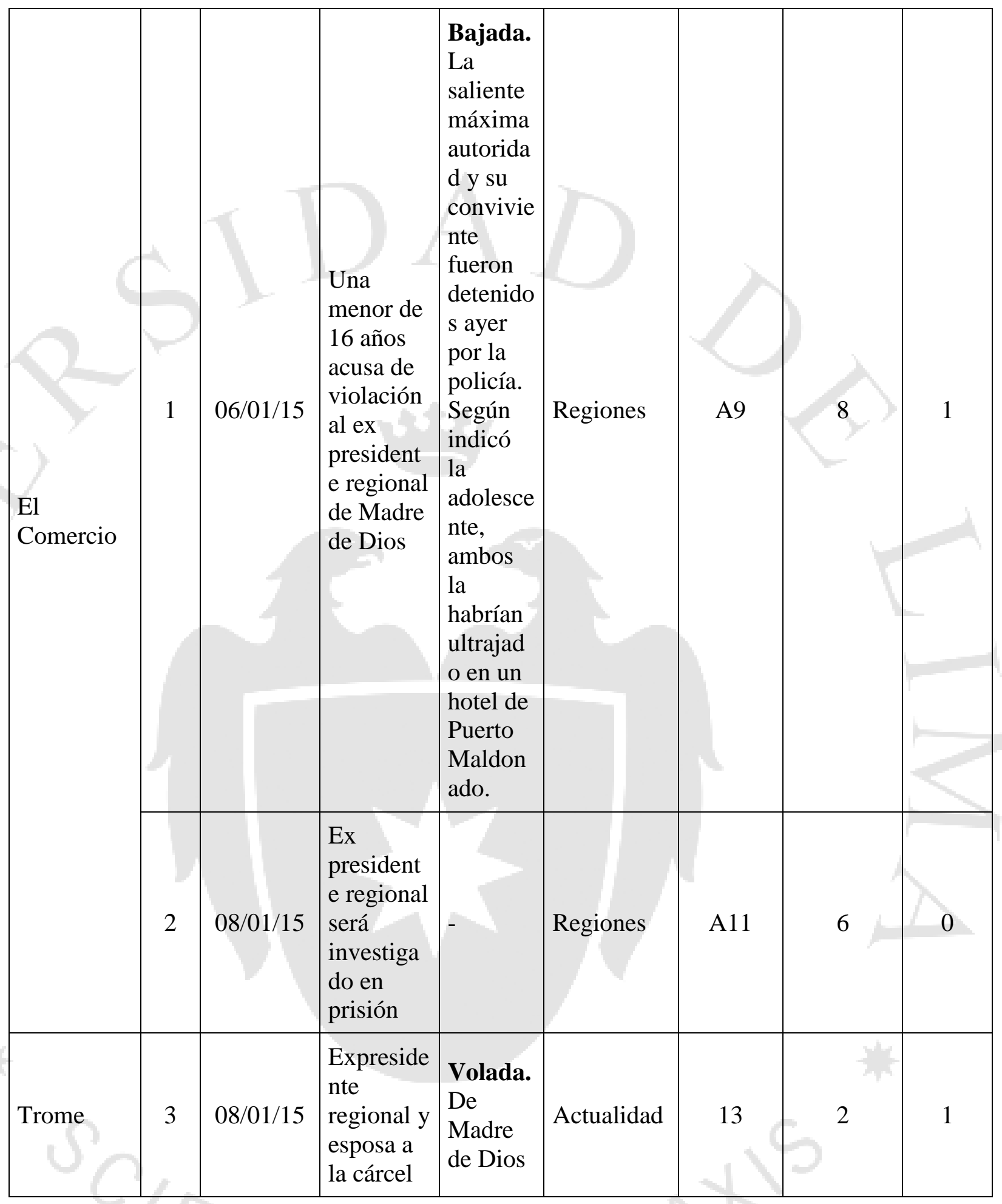




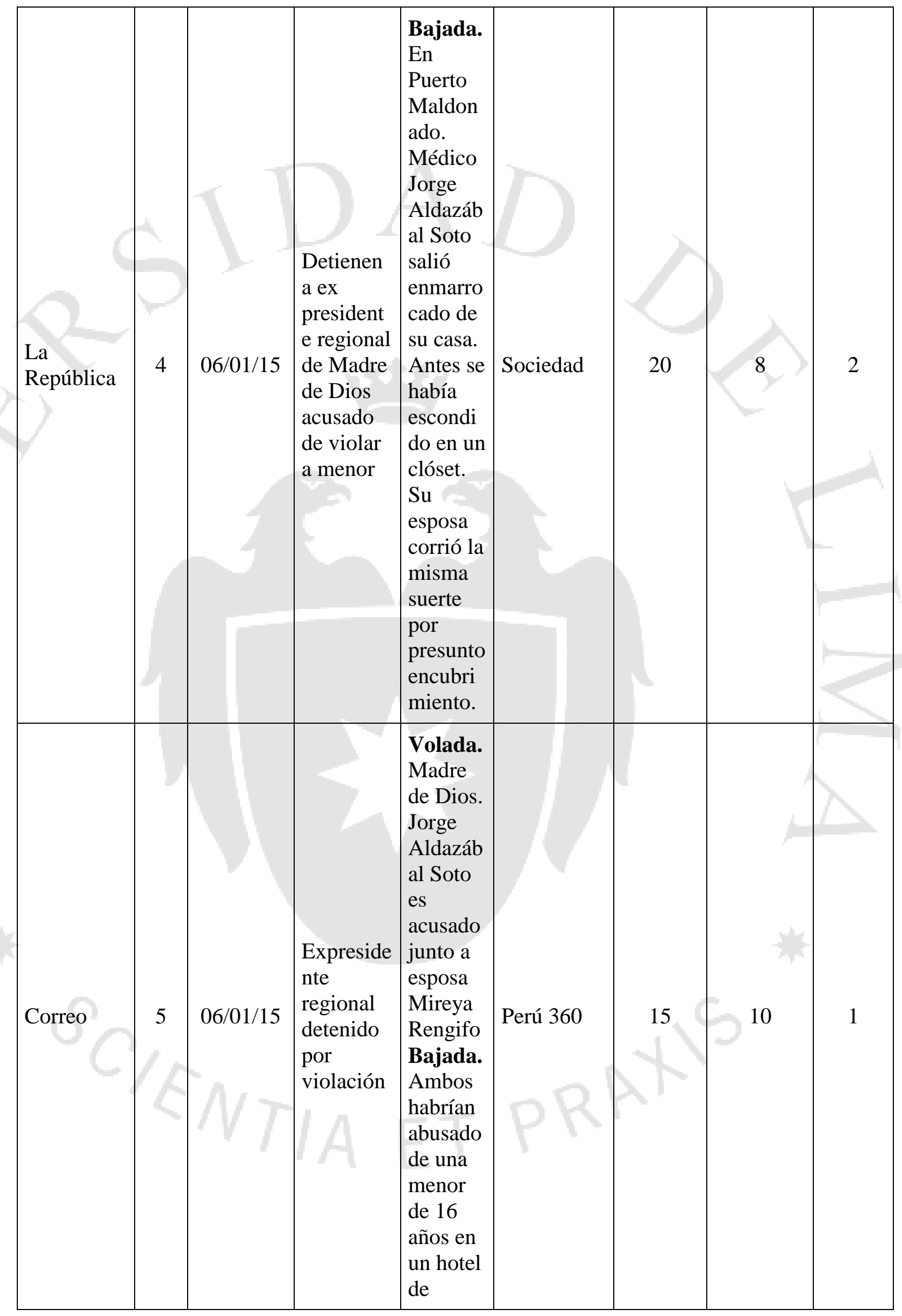




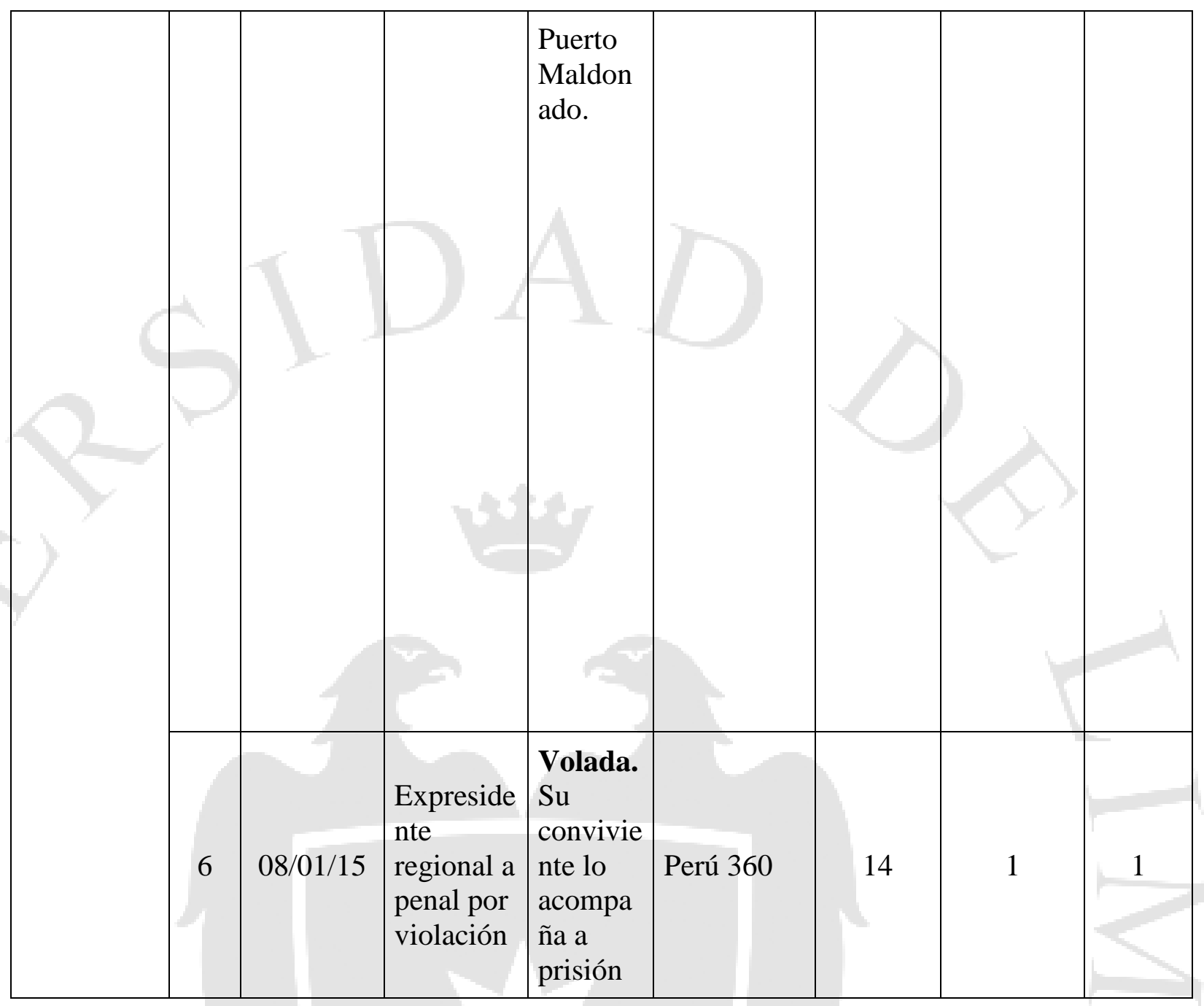

